\title{
RADICALIZANDO A DEMOCRACIA, REDEFININDO A ESFERA PÚBLICA, REDESENHANDO INSTITUIÇÕES: UM ENSAIO PARA MAIOR PARTICIPAÇÃO POPULAR NA POLÍTICA
}

\author{
RADICALIZING DEMOCRACY, REDEFINING PUBLIC SPHERE, REDESIGNING \\ INSTITUTIONS: AN ESSAY ABOUT INCREASING POPULAR PARTICIPATION IN \\ POLITICS
}

\section{RADICALIZANDO LA DEMOCRACIA, REDEFINIENDO LA ESFERA PÚBLICA, REDISEÑANDO INSTITUCIONES: UN ENSAYO PARA MAYOR PARTICIPACIÓN CIUDADANA EN LA POLÍTICA}

\author{
KATYA KOZICKI \\ https://orcid.org/0000-0002-2388-0499 / http://lattes.cnpq.br/8804746815321094 / kkozicki@uol.com.br \\ Universidade Federal do Paraná. \\ Pontifícia Universidade Católica do Paraná. \\ Curitiba, PR, Brasil.
}

\begin{abstract}
MARIA HELENA Fonseca FaLLeR https://orcid.org/0000-0003-4458-1946 / http://lattes.cnpq.br/4934559490717418 / mhfaller@outlook.com Pontifícia Universidade Católica do Paraná.
\end{abstract}

Curitiba, PR, Brasil.

\begin{abstract}
RESUMO
As democracias contemporâneas vivenciam um processo de esgotamento das certezas e dos paradigmas que as sustentaram durante décadas. É necessário repensar seus fundamentos e reformular suas instituições centrais. Nas sociedades complexas e plurais atuais, a questão da necessidade de maior partilha do poder político impõe-se fortemente, uma vez que a definição da política deve ser discutida por quem será afetado por ela. A partir dessa perspectiva, este trabalho articula a matriz teórica da democracia radical com as teorias de desenhos institucionais democráticos e esferas públicas plurais para verificar se proporcionariam maior participação popular na definição da política. Conclui-se que a radicalização democrática comporta e favorece a noção de esfera(s) pública(s) plurais, com instituições desenhadas democraticamente, de forma a potencializar o acesso ao poder político pelo povo, ampliando e qualificando a participação popular na construção das democracias.
\end{abstract}

Palavras-chave: Democracia radical; Esferas públicas plurais; Desenhos institucionais democráticos; Participação popular.

\begin{abstract}
Contemporary democracies are undergoing a process of exhaustion of the convictions and paradigms which for decades have sustained them. To rethink their foundations and redesign their core institutions are necessary steps. The necessity for increased political power sharing imposes questions strongly felt in the complex and plural contemporary societies, since the definition of politics must be discussed among those who will be affected by it. From this perspective, this paper articulates the theoretical matrix of radical democracy with democratic institutional design and multiple public sphere theories, to check whether they propitiate an increased popular participation in the definition of politics. It concludes that a democratic radicalization entails and promotes the notion of plural public sphere, with democratically designed institutions in order to potentialize greater access by the people to the political power, thus increasing popular participation in the construction of democracies.
\end{abstract}

Keywords: radical democracy; public sphere; democratic institutional designs; popular participation. 


\section{RESUMEN}

Las democracias contemporáneas experimentan un proceso de agotamiento de las certezas y de los paradigmas que las han sostenido durante décadas. Es necesario repensar sus fundamentos y reformular sus instituciones centrales. En las actuales sociedades complejas y plurales, un mayor compartir del poder político se impone fuertemente, puesto que la definición de la política debe ser debatido por quien será afectado por ella. Desde esta perspectiva, este ensayo articula la matriz teórica de la democracia radical con las teorías de diseños institucionales democráticos y esferas públicas múltiples, para un posible incremento de la participación ciudadana en la definición de la política. Concluye que la radicalización democrática acepta y favorece la noción de esfera(s) pública(s) plurales, con instituciones diseñadas democráticamente, para desarrollar un mayor acceso al poder político por el pueblo, aumentando e cualificando la participación ciudadana en la construcción de las democracias.

Palabras clave: democracia radical; esferas publicas plurales; diseños institucionales democráticos; participación ciudadana

\section{SUMÁRIO}

INTRODUÇÃO; 1 PREMISSAS: POLÍTICA E PODER; 2 A DEMOCRACIA RADICAL E A POLITÍCA DEMOCRÁTICA; 3 ESFERAS PÚBLICAS PLURAIS PARA UMA DEMOCRACIA RADICAL; 4 DESENHOS INSTITUCIONAIS DEMOCRÁTICOS; CONCLUSÃO; REFERÊNCIAS.

\section{INTRODUÇÃO}

Pensar e construir uma democracia nos dias atuais é um grande desafio, pois, hoje, vive-se um processo acelerado de desarticulação das certezas e paradigmas que sustentaram a existência dos regimes democráticos modernos, os quais construíram suas narrativas ao redor das ideias de autogoverno, soberania popular e representação, concebidos no contexto do Estado Nação. Nesse cenário, as constituições modernas se ocupavam em estabelecer as regras vitais do jogo democrático, por meio da garantia de direitos e da organização da estrutura de poder.

Nas últimas décadas, as democracias (e, consequentemente, as constituições) têm sofrido crises e ataques frequentes, que partem dos mais variados matizes e perspectivas culturais. Uma questão se coloca de modo central: a complexificação das formas de vida, a crise do Estado-Nação e a fragilização da representação enquanto instituição central nas democracias constitucionais exigem uma reflexão sobre sua compreensão para além das estruturas de pensamento e narrativas convencionais, consagradas no pensamento político moderno. ${ }^{1}$

\footnotetext{
${ }^{1}$ Nesse sentido, James Tully propõe a filosofia política como atividade crítica, na qual se conceda certo primado para a prática, questionando, a partir disso, as estruturas teóricas e reais que geram opressões, desde a análise de novas condições de possibilidade e de novas gramáticas que desafiem a linguagem consagrada e permitam a autocompreensão dos sujeitos, permitindo-lhes perceber modos diferentes de governar e de narrar. Essas investigações filosóficas permanecem em uma relação recíproca com o presente, como uma espécie de crítica política permanente das relações de poder, das subjetividades, da forma como pensamos e agimos politicamente. In: TULLY, James. Public Philosophy in a New Key. Volume I: Democracy and Civic Freedom. [Local]: Cambridge University Press, 2009. Disponível em
} 
ISSN 1981-3694

(DOI): $10.5902 / 1981369434534$

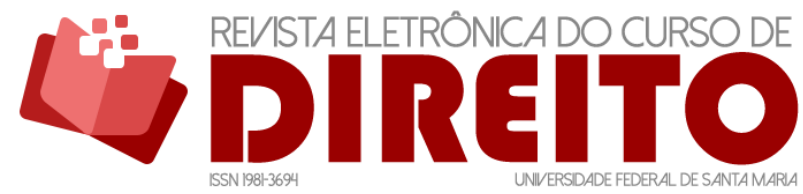

RADICALIZANDO A DEMOCRACIA, REDEFININDO A ESFERA PÚBLICA, REDESENHANDO INSTITUIÇÕES: UM ENSAIO PARA MAIOR PARTICIPAÇÃO POPULAR NA POLÍTICA

KATYA KOZICKI MARIA HELENA FONSECA FALLER

Nessa perspectiva, a matriz teórica da democracia radical possui contribuições importantes ao inserir dimensões marginais no centro da filosofia política - paixão e afeto como seus elementos constitutivos - e ao possibilitar a assunção do conflito como elemento característico do político, sugerindo a criação de formas democráticas que permitam sua expressão e sua canalização, o que possibilita a vida democrática em sociedades plurais.

Não há como falar em democracia sem pensar no debate acerca da esfera pública, ${ }^{2}$ e de certo esgotamento dos espaços políticos formais e tradicionais, como os poderes legislativo e executivo, além de seus canais de expressão e escuta (ou debate) social. A sociedade de massa, com toda sua complexidade, não encontra expressão em uma ideia de bem público reduzido aos interesses gerais e únicos, com decisões produzidas estritamente no âmbito estatal. ${ }^{3} \mathrm{~A}$ política democrática radical $^{4}$ requer que seja repensada a esfera pública como espaço plural, que permita a expressão do pluralismo e do conflito, de modo que os antagonismos possam ser canalizados e domesticados sem eliminação do diferente, evitando a conversão do conflito em violência.

Refletir sobre esferas públicas plurais em um contexto de democracia radical, conforme propõe Chantal Mouffe, exige a reavaliação dos desenhos institucionais democráticos, ${ }^{5}$ de modo que sejam construídos para permitir a potencialização e a qualificação da participação popular, gerando melhor redistribuição do poder político. 0 poder constitui as relações sociais e, admitindo essa premissa, torna-se possível pensá-lo a partir de formas compatíveis com os

http://www.cambridge.org/br/academic/subjects/politics-international-relations/politicaltheory/public-philosophy-new-key-volume-2?format=PB\&isbn=9780521728805. Acesso em: 28 maio 2019.

${ }^{2}$ A concepção de esfera pública adotada neste trabalho reconhece as mais variadas expressões, recantos e recessos das sociedades e dos Estados como espaço público legítimo. In: KEANE, John. A sociedade civil. Tradução Mario José Figueiredo. Lisboa: Temas e Debates, 2001.

${ }^{3}$ KEANE, John. A sociedade civil. Tradução Mario José Figueiredo. Lisboa: Temas e Debates, 2001, p. 195 e sS.

${ }^{4}$ A ideia de política democrática radical é extraída do pensamento de Chantal Mouffe, a qual propõe a construção da política a partir do reconhecimento da diferença, do conflito e do poder, a partir de espaços institucionais que permitam sua expressão e canalização, proporcionando a existência de diversos modos de vida na comunidade política, sem eliminações e violências. 0 pluralismo torna a democracia vibrante. In: MOUFEE, Chantal. Sobre o político. Tradução Fernando Santos, São Paulo: WMF Martins Fontes, 2015.

${ }^{5}$ As teorias dos desenhos institucionais democráticos propõem a criação de instituições democráticas que favoreçam a participação, permitindo que as decisões e deliberações realizadas nesses espaços condicionem, efetivamente, a criação das políticas. A deliberação pública e democrática está intimamente relacionada ao desenho institucional, que deve favorecer a articulação entre debate e participação pública nas decisões políticas. In: CUNHA, Eleonora Schettini M; THEODORO, Hildelano Delanusse. (Orgs). Desenho institucional, democracia e participação: conexões teóricas e possibilidades analíticas. [Local]: D 'Placido Editora, 2014. 
valores democráticos. ${ }^{6}$ É o poder político que permite a ação humana no mundo. 0 pensamento constitucional moderno estabelece que o poder político tem titularidade popular.

Se a soberania é popular, como define a Constituição, é preciso pensá-la teoricamente com vistas a torná-la práxis política. Nesse sentido, este trabalho pretende avaliar em que medida a matriz teórica da democracia radical, colocada em um contexto de esferas públicas plurais, compostas por desenhos institucionais democráticos, possibilitaria maior e mais qualificada participação popular na política, gerando melhor distribuição do poder político, compreendido como a condição de agir e interferir na construção do mundo. ${ }^{7}$

Parte-se da hipótese de que a radicalização democrática comporta e favorece a noção de esferas públicas plurais, com instituições desenhadas democraticamente de forma a potencializar um maior acesso ao poder político pelo povo, aumentando e qualificando a participação popular na construção das democracias. Para isso, objetiva-se refletir sobre: (i) as perspectivas de política e de poder de Hannah Arendt e de Chantal Mouffe; (ii) as concepções de democracia radical e a política democrática de Chantal Mouffe e John Dewey; (iii) os desenhos institucionais democráticos pensados a partir de esferas públicas plurais.

A concepção de democracia que fundamenta esse exercício reflexivo pauta-se no princípio de que todos devem ser tratados com igual respeito e consideração. Igualdade no sentido de que todas as pessoas possuem a mesma dignidade moral e são iguais em suas capacidades mais básicas. A ideia de que há pessoas, dentro do sistema democrático, que possuem status superior em relação às demais, por qualquer razão que seja, é injustificável. ${ }^{8}$ Todos os indivíduos possuem igual direito de intervir nos assuntos que afetam a sua comunidade

\footnotetext{
${ }^{6}$ MOUFEE, Chantal. Sobre o político. Tradução Fernando Santos, São Paulo: WMF Martins Fontes, 2015, p. 08.

${ }^{7}$ Este artigo trabalha com a proposta de aumentar e qualificar o exercício da participação popular. A qualificação desta participação ocorre à medida que seu exercício se torna mais frequente e mais amplo. Carole Pateman é uma referência neste tema e defende a ideia de que a participação democrática é pedagógica, ou seja: aprende-se a participar, participando. In: PATEMAN, Carole. Participação e teoria democrática. São Paulo: Paz e Terra, 1992.

${ }^{8}$ Importante registrar a influência do pensamento kantiano na construção moderna do conceito de pessoa, como sujeito livre e pensante. 0 sujeito kantiano é dotado de uma capacidade subjetiva que o permite decidir motivado por uma vontade livre (autônoma), que é o querer da razão, a qual independe da influência externa (razão pura). Para Kant, a pessoa é o sujeito moral, que em seu âmbito prático realiza suas ações de forma livre, independente de motivação e conhecimento externos e independente do desejo. A liberdade é concebida como um elemento ontológico do ser humano, condição para sua capacidade de autodeterminação, escolha e responsabilização. In: KANT, Immanuel. Fundamentação da metafísica dos costumes e outros escritos. São Paulo: Martin Claret, 2005.
} 
ISSN 1981-3694

(DOI): $10.5902 / 1981369434534$

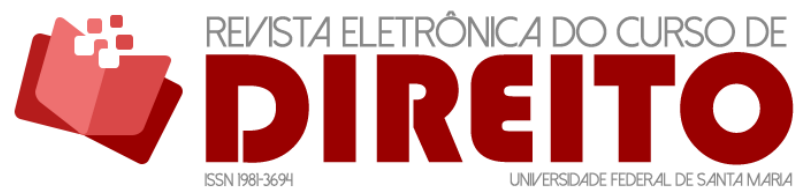

RADICALIZANDO A DEMOCRACIA, REDEFININDO A ESFERA PÚBLICA, REDESENHANDO INSTITUIÇÕES: UM ENSAIO PARA MAIOR PARTICIPAÇÃO POPULAR NA POLÍTICA

KATYA KOZICKI MARIA Helena FonseCA FALler

e merecem participar do processo decisório em pé de igualdade, entendida como iguais consideração e respeito por cada um. ${ }^{9}$

O método de abordagem utilizado será o dedutivo, com técnica de pesquisa bibliográfica.

\section{PREMISSAS: POLÍTICA E PODER}

Chantal Mouffe realiza uma importante distinção entre o político e a política: o primeiro é essencialmente antagonismo, enquanto a segunda é formada pelo conjunto de "práticas e instituições por meio das quais uma ordem é criada, organizando a coexistência humana no contexto conflituoso produzido pelo político". ${ }^{10}$

A política, segundo Hannah Arendt, trata daquilo que as pessoas realizam quando se colocam juntas no mundo. O pensamento de Arendt parte de pressupostos distintos de Mouffe, uma vez que, para pensar o político, adota como ponto de partida as concepções gestadas no período clássico, concebendo-o como espaço de liberdade. Chantal Mouffe, por sua vez, assume a perspectiva de que o político é espaço de poder, de conflito e de antagonismo.

É possível dizer que Arendt e Mouffe reconhecem o conflito como elemento constitutivo da política, embora o façam sob compreensões bastante diversas. A ideia aqui não é colocá-las lado a lado com o intuito de realizar uma síntese deformadora de suas teorias, mas trata-se de uma tentativa de reuni-las nessa reflexão motivada pelo pensamento de que o conflito, o poder e a liberdade não são elementos irreconciliáveis. A partir disso, uma primeira premissa é estabelecida: a reflexão nasce da ideia de que a política é o espaço em que os conflitos se colocam e se expressam, o que a constitui de modo vital. Porém, é preciso ir mais além, primeiramente, pelas mãos de Hannah Arendt.

A política, de acordo com a autora, é similar ao exercício de liberdade e baseia-se na pluralidade dos homens, ocupando-se do convívio entre os diferentes. Não obstante todas as experiências perversas com o político, é “evidente que o homem é dotado, de uma maneira

\footnotetext{
${ }^{9}$ DWORKIN, Ronald. A virtude soberana: a teoria e prática da igualdade. Trad. Jussara Simões. 2 ed. São Paulo: WMF Martins Fontes, 2011, p. I- XVIII.

${ }^{10}$ MOUFEE, Chantal. Sobre o político. Tradução Fernando Santos, São Paulo: WMF Martins Fontes, 2015, p. 08 e ss.
} 
ISSN 1981-3694

(DOI): $10.5902 / 1981369434534$

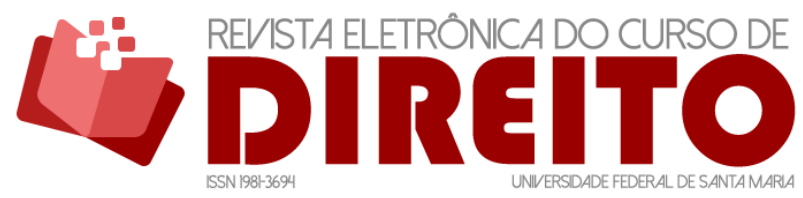

RADICALIZANDO A DEMOCRACIA, REDEFININDO A ESFERA PÚBLICA, REDESENHANDO INSTITUIÇÕES: UM ENSAIO PARA MAIOR PARTICIPAÇÃO POPULAR NA POLÍTICA

KATYA KOZICKI MARIA HELENA FONSECA FALLER

altamente maravilhosa e misteriosa, do dom de fazer milagre", de agir, de impor um novo começo. ${ }^{11}$

Nas palavras de Arendt, “o milagre da liberdade está contido nesse poder começar que, por seu lado, está contido no fato de que cada homem é em si um novo começo, já que através do nascimento veio ao mundo que existia antes dele e continuará existindo depois dele". ${ }^{12}$ Admite, dessa forma, as experiências atrozes conduzidas pela política, sem negar sua capacidade inesgotável de renovar e impor um novo começo, caracterizada por ser terreno de liberdade e espontaneidade. Essa é a possibilidade de manter a dimensão humana presente na política.

Segundo Kurt Sontheimer, Arendt não se acomoda nas categorias direita e esquerda e é, tampouco, uma realista ou idealista. Não mantém ilusão sobre o estado do mundo, mas é firme ao propor que são necessárias mudanças e aconselha ter em mente o que chama de essencial. ${ }^{13}$

Assim,

Essa reflexão levou-a, em vista do primado da necessidade e do cuidado com a existência, dominante da política, a relacionar a política com chance e espaço da liberdade, ao frisar a importância do agir e da realização pessoal, em comparação com a fixação da pura produção de produtos a contrapor o valor mais elevado da felicidade pública à caça do interesse e à boa vida. ${ }^{14}$

Nessa perspectiva, a política é concebida como relação. Não se trata de uma substância política original e essencial, mas de algo que nasce no intraespaço, no estar no mundo. Organiza as diversidades absolutas de acordo com a igualdade relativa e, em contrapartida, às diferenças relativas.

Percebe-se, no pensamento da autora, a busca constante de dar, à política, sua dimensão eminentemente humana e de responsabilidade também pessoal. É recorrente encontrar críticas dirigidas à burocracia estatal, a qual indica “domínio de ninguém”. ${ }^{15}$ Pensar a política como domínio da burocracia permite o desaparecimento de toda possibilidade de

\footnotetext{
11 ARENDT, Hannah. 0 que é política? Tradução de Reinaldo Guarany. 10 ed. Rio de Janeiro: Bertrand Brasil, 2012, p. 20.

12 ARENDT, Hannah. O que é política? Tradução de Reinaldo Guarany. 10 ed. Rio de Janeiro: Bertrand Brasil, 2012, p. 43.

${ }^{13}$ SONTHEIMER, Kurt. Prefácio. In: ARENDT, Hannah. 0 que é política? Tradução de Reinaldo Guarany. 10 ed. Rio de Janeiro: Bertrand Brasil, 2012, p.16 e ss.

${ }^{14}$ SONTHEIMER, Kurt. Prefácio. In: ARENDT, Hannah. 0 que é política? Tradução de Reinaldo Guarany. 10 ed. Rio de Janeiro: Bertrand Brasil, 2012, p. 10.

${ }^{15}$ ARENDT, Hannah. Sobre a violência. Tradução de André Duarte. Rio de Janeiro: Civilização Brasileira, 2000, p. 55
} 
interromper processos de tirania e de realização de mudanças, pois se aceita a realidade como algo que se impõe, ou seja, que é inescapável.

Em suas palavras:

O que não pode servir para acalmar nossas preocupações ao constatarmos que, nas democracias de massa, sem nenhum terror e de modo quase espontâneo, por um lado toma vulto uma impotência do homem e por outro aparece um processo similar de consumir e esquecer, como que girando em torno de si mesmo de forma continua, embora esses fenômenos continuem restritos, no mundo livre e não-arbitrário, à coisa política em seu sentido mais literal e à coisa econômica. ${ }^{16}$

A liberdade de agir não pode prescindir da presença de outros e de ser confrontado com suas opiniões. Para conhecer o mundo em sua realidade e em sua objetividade, é necessário olhá-lo junto a e a partir de outros olhares, caso contrário a expressão será sempre da perspectiva de apenas uma posição de mundo, porque "só na liberdade do falar um com o outro nasce o mundo sobre o qual se fala, em sua objetividade visível de todos os lados". ${ }^{17}$ A política, nesse sentido, estabelece-se nas relações e, justamente por esse fato, é indissociável da diferença e dos conflitos.

A ideia de Arendt é iniciar o projeto sobre a política no contexto da diferença ontológica de Heidegger, ${ }^{18}$ no qual a política faz a diferença e permite a possibilidade do novo. Para isso, estabelece a pergunta sobre os outros e sobre a diferença, propondo a superação da metafísica da presença pelo pensamento da diferença, pois seu entendimento é de que a política pode, ou não, acontecer entre as pessoas, uma vez que não são seres políticos por natureza. Assim, só existe política se existem interações e relações entre os seres humanos. A partir de tal compreensão, libera-se da ontologia heideggeriana e das questões postas por Husserl presentes

\footnotetext{
${ }^{16}$ ARENDT, Hannah. 0 que é política? Tradução de Reinaldo Guarany. 10 ed. Rio de Janeiro: Bertrand Brasil, 2012, p. 27.

17 ARENDT, Hannah. $O$ que é política? Tradução de Reinaldo Guarany. 10 ed. Rio de Janeiro: Bertrand Brasil, 2012, p. 60.

${ }^{18}$ Segundo Milovico, pensamento político moderno é marcado por uma concepção filosófica, denominada como metafisica da presença, que parte do ser e da identidade como condição de construção dos sentidos e da realidade. A proposta de Arendt é trabalhar com o pensamento da diferença, o qual busca separar a vida de uma elaboração metafísica, ligando-a à condição humana. A inspiração fenomenológica e heideggeriana fica clara, pois pensar a política significa separar-se da metafísica e do essencialismo. Para Arendt, a política é o lugar da ruptura com a metafísica o qual reconhece a condição humana, a presença do outro e a necessidade de interação como condição de construção dos sentidos e do mundo. Para aprofundar essa proposta, ver: MILOVIC, Miroslav. Considerações sobre Hannah Arendt e Chantal Mouffe. Disponível em: https://revistacult.uol.com.br/home/a-condicao-humana-na-modernidade/. Acessado em 28 de maio de 2019.
} 
ISSN 1981-3694

(DOI): $10.5902 / 1981369434534$

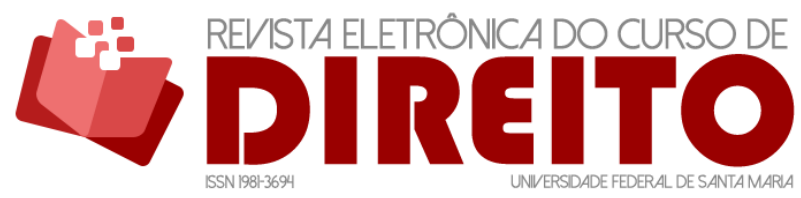

RADICALIZANDO A DEMOCRACIA, REDEFININDO A ESFERA PÚBLICA, REDESENHANDO INSTITUIÇÕES: UM ENSAIO PARA MAIOR PARTICIPAÇÃO POPULAR NA POLÍTICA

KATYA KOZICKI Maria Helena Fonseca Faller

em seu pensamento de que "os outros são pressupostos e não só consequências de uma reflexão solitária”. ${ }^{19}$

Nesse sentido, a contribuição importante de Hannah Arendt é incluir a interação no projeto político da diferença. Chantal Mouffe e Hannah Arendt compartilham a visão da política como um espaço de expressão da diferença, embora o façam sob fundamentos divergentes. Mouffe entende que Arendt fala de pluralidade como um meio para se alcançar o consenso, argumento fortemente criticado. ${ }^{20}$

Chantal Mouffe deseja reconhecer a política como espaço de conflito, de pluralismo, que deve ser orientado e enfrentado de maneira política. Questões políticas sempre envolverão decisões que optem por alternativas conflitantes e há conflitos que jamais poderão ser resolvidos por meio de argumentos racionais, conforme apregoa a perspectiva liberal. Isso porque a política é um espaço em que reina a hegemonia de quem possui o poder.

A realização de consensos, tão difundida nas discussões democráticas e políticas, fundamenta-se em atos de exclusão, uma vez que as consonâncias racionais não são plenamente inclusivas. 0 antagonismo, como elemento inerradicável do político, revela o limite de qualquer consenso racional, assim, Mouffe enfrenta os dois paradigmas essenciais liberais: o agregativo e o deliberativo. No agregativo, explicita que a ideia de compromisso entre forças discordantes parte de uma compreensão de mercado aplicada à esfera política. O deliberativo constrói-se como reação ao primeiro, mantendo-se em uma esfera moral, uma vez que acredita ser possível criar consensos morais racionais por meio de debates livres. ${ }^{21}$

A compreensão do político como antagonismo e a natureza conflituosa da política não são antiéticas em relação ao projeto democrático, como é recorrente escutar (ou ler), contudo, a compreensão da política como espaço de relação amigo/inimigo, classicamente desenvolvida por Carl Schmitt, é importante ponto de partida para pensar a política democrática e a democracia radical.

Schmitt pensa a democracia como uma totalidade homogênea, ${ }^{22}$ uma vez que a relação amigo/inimigo caracteriza a política e implica a eliminação do inimigo do jogo democrático. Sua

19 MILOVIC, Miroslav. Considerações sobre Hannah Arendt e Chantal Mouffe. Disponível em: https: //revistacult.uol.com.br/home/a-condicao-humana-na-modernidade/. Acesso em: 28 maio 2019.

20 SAN MIGUEL, Mercedes López. "A política tem a ver com conflito" Entrevista de Chantal Mouffe. Disponível em: https://www.cartamaior.com.br/?/Editoria/Pelo-Mundo/Chantal-Mouffe-A-politica-tem-aver-com-o-conflito-/6/16166. Acesso em: 28 maio 2019.

${ }^{21}$ MOUFEE, Chantal. Sobre o político. Tradução Fernando Santos, São Paulo: WMF Martins Fontes, 2015, p. $10-12$.

22 Sobre o pensamento de Schmitt, ver: SCHMITT, Carl. Teologia Politica I e II - Nova edição atualizada. Buenos Aires: Struhart, 2005. 
ISSN 1981-3694

(DOI): $10.5902 / 1981369434534$

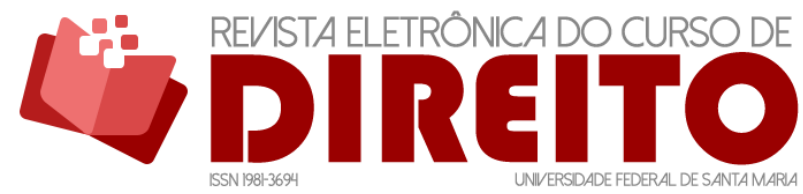

RADICALIZANDO A DEMOCRACIA, REDEFININDO A ESFERA PÚBLICA, REDESENHANDO INSTITUIÇÕES: UM ENSAIO PARA MAIOR PARTICIPAÇÃO POPULAR NA POLÍTICA

KATYA KOZICKI MARIA HELENA FONSECA FALLER

tese sobre as identidades políticas que daí emergem é muito importante para compreender a política democrática, porquanto a relação amigo/inimigo revela a natureza relacional de todas as identidades e, também, o conceito de exterioridade constitutiva, fundamental para se pensar que aquelas se formam a partir do estabelecimento de uma diferença. Desse modo, "toda identidade é relacional e a afirmação da diferença é uma precondição para a existência de qualquer identidade, ou seja, a percepção de um outro que constitui o seu exterior". ${ }^{23}$

A criação de um "nós" e de um "eles" revela o antagonismo e o conflito, a diferença como algo insuperável. Schmitt resolveu essa questão com o estabelecimento da relação amigo/inimigo, que resultava na eliminação do "eles" do jogo democrático. Os resultados da concretização da teoria são inumeráveis e estão todos os dias à disposição de quem quiser enxergar. ${ }^{24}$ Sob o argumento de construir consensos, ignoram-se as diferenças, que são excluídas da política, o que as transforma em refugos que a comunidade deve expelir para manter-se "em ordem".

O que Mouffe propõe é imaginar outros métodos políticos da construção do nós/eles que permitam transformar o antagonismo (condição ontológica do político) em agonismo (relação adversarial), em que o diferente não é eliminado, mas reconhecido e mantido em condições de continuar o pleito pela hegemonia no jogo democrático. Usando as mesmas palavras da autora, "toda ordem é política e se baseia em alguma forma de exclusão. Sempre existem outras possibilidades, que foram reprimidas e que podem ser reativadas, [...] toda ordem hegemônica é passível de ser desafiada por práticas anti-hegemônicas". ${ }^{25}$

Nesse sentido, uma das principais tarefas da política democrática é transformar o antagonismo das relações, compreendendo o conflito como legítimo e impedindo que ele destrua o ente político. Para isso, é preciso criar formas que possibilitem vínculos comuns entre as partes em conflito, em que o "nós/eles" assuma uma forma agonística, de relação adversarial, em que ninguém é eliminado. 0 modelo adversarial proposto por Chantal Mouffe admite que a

${ }^{23}$ MOUFEE, Chantal. Sobre o político. Tradução Fernando Santos, São Paulo: WMF Martins Fontes, 2015, p. 14.

${ }^{24}$ O nazismo foi uma representação concreta da eliminação do diferente da comunidade política. As guerras políticas do Oriente Médio se justificam pela manutenção de uma identidade religiosa comum que se opõe a uma identidade religiosa diferente, a qual deve se retirar e ser combatida. Para não ir muito longe, pode-se pensar no cotidiano: experiências de ataques homofóbicos ou de exercício de práticas racistas, partem de um pressuposto simbólico comum de que o diferente deve ser eliminado por representar uma ameaça à ordem existente.

${ }^{25}$ MOUFEE, Chantal. Sobre o político. Tradução Fernando Santos, São Paulo: WMF Martins Fontes, 2015, p. 17. 
política democrática transforme antagonismo em agonismo, evitando que antagonismos se transformem em exclusão, o que, por fim, desemboca em violências. ${ }^{26}$

Essa passagem da autora resume de forma clara seu pensamento:

Não há dúvida de que o consenso é necessário, mas ele precisa estar acompanhado do dissenso. Embora o consenso seja necessário no que diz respeito às instituições constitutivas da democracia e aos valores "ético-políticos" que caracterizam a associação política - liberdade e igualdade para todos - sempre haverá discordância quanto ao seu significado e quanto ao modo como devem ser implementados. Numa democracia pluralista, essas discordâncias não são apenas legítimas, mas também necessárias. Elas fornecem matéria-prima da política democrática. ${ }^{27}$

Para tanto, são necessárias instituições políticas efetivamente democráticas, que ofereçam espaço e canais de expressão para as vozes discordantes. É preciso haver instituições que permitam a expressão do conflito com liberdade.

A articulação do pensamento de Mouffe e Arendt, respeitadas e ressalvadas suas profundas diferenças, ${ }^{28}$ permite pensar a política como liberdade, como poder de agir no mundo e como possibilidade de iniciar novos processos, construir novas narrativas e experiências democráticas. A existência de conflitos e de jogos de poder e a aceitação do político como antagonismo não interferem na compreensão de que a política é espaço de liberdade, onde os sujeitos podem se expressar nas instituições, canalizando suas forças e lutas diárias.

Mesmo se vencidas em suas posições, as pessoas não podem deixar de ser reconhecidas e respeitadas como sujeitos de direitos, que permanecem na busca pela realização de suas aspirações e interesses - como a liberdade para se expressar, para se colocar, para lutar.

${ }^{26}$ Ellen Kennedy realizou uma releitura do pensamento de Carl Schimitt que desconstrói a interpretação comum que sua teoria teria servido como fundamento teórico para o desenvolvimento das concepções políticas do nazismo. Segundo a autora, as críticas de Schimitt ao liberalismo não o transformaram em um teórico do totalitarismo, mas apenas apontavam as fraquezas da concepção liberal: o primado da lei e da sua racionalidade formal e os consensos racionais daí decorrentes não eram suficientes para se ocupar da complexidade do político, com a existência da diferença e do conflito. De fato, Schimitt acreditava que a identidade política é relacional e se constituía a partir da existência da diferença, a qual seria uma característica indissociável do político. Ver a propósito: KENNEDY, Ellen. Constitutional Failure: Carl Schmitt in Weimar. NC: Duke University Press, 2004.

${ }^{27}$ MOUFFE, Chantal. O regresso do político. Lisboa: Gradiva, 1996, p. 30.

28 É importante considerar que existe uma compreensão comum das duas autoras no que se refere à afirmação de que a política enfrenta, atualmente, um profundo esvaziamento de sentidos, o que acarreta um processo de desintegração e confusão de limites entre o campo moral, campo jurídico e o campo político. Questões políticas são resolvidas como questões morais e/ou jurídicas. In: MILOVIC, Miroslav. Arendt. 0 otimismo pensando a dignidade da política. Disponível em: http: / / www.ihuonline.unisinos.br/index.php?option=com_content\&view=article\&tid=621\&secao=206. Acesso em: 28 maio 2019. 
ISSN 1981-3694

(DOI): $10.5902 / 1981369434534$

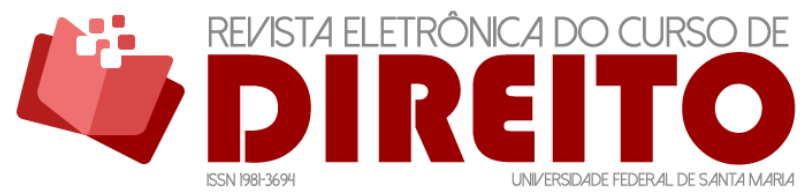

RADICALIZANDO A DEMOCRACIA, REDEFININDO A ESFERA PÚBLICA, REDESENHANDO INSTITUIÇÕES: UM ENSAIO PARA MAIOR PARTICIPAÇÃO POPULAR NA POLÍTICA

KATYA KOZICKI MARIA HELENA FONSECA FALLER

Também a liberdade para aceitar uma vitória diversa da esperada ou um resultado diferente do desejado, permanecendo vivo e capaz de continuar a reivindicar suas pautas e agendas.

Por fim, é preciso definir que o poder é aqui compreendido como capacidade humana de agir, de definir e de determinar ou se autodeterminar. Surge o poder em todos os lugares nos quais os sujeitos agem conjuntamente e, como o agir em comum acontece, essencialmente, no espaço político, o poder potencial inerente a todos os assuntos humanos se faz valer em um espaço dominado pela força. Com isso, surge a ilusão de que poder e força são idênticos quando, na verdade, não, chegando a constituírem verdadeiro antagonismo. ${ }^{29}$

É recorrente confundir o poder com pressão e violência. De fato, estes foram meios utilizados para proteger o espaço político, para fundá-lo ou para ampliá-lo, mas não são políticos como tal, visto que constituem fenômenos marginais à política, mas que com ela não se confundem. ${ }^{30}$ Segundo Arendt, são coisas distintas, assim,

[...] o poder é de fato a essência de todo governo, e não a violência. A violência é por natureza instrumental: como todos os meios, ela sempre depende da orientação e da justificação pelo fim que almeja. E aquilo que necessita de justificação por outra coisa não pode ser essência de nada. 0 fim da guerra - fim tomado em seu duplo sentido - é a paz ou a vitória; mas para a questão "e qual é o fim da paz" não há resposta. A paz é um absoluto, mesmo se na história registrada os períodos de guerra quase sempre superaram os períodos de paz. 0 poder está na mesma categoria; ele é, como se diz, "um fim em si mesmo". ${ }^{31}$

A Constituição determina que "todo o poder emana do povo". ${ }^{32}$ Assim, o fundamento do poder político é o povo, que indica representantes para exercê-lo, contudo, a soberania permanece popular. Isso significa que a capacidade de agir, de determinar, de criar e de definir a política e irromper com o novo é, primeiramente, do povo, o qual, por sua vez, necessita de espaços e instituições que o permitam exercer seu autogoverno, para além dos espaços democráticos representativos tradicionais, como poder legislativo e executivo. Esses espaços serão marcados pela existência de conflitos e múltiplas concepções e modos de vida, que deverão ser, necessariamente, reconhecidos e acolhidos na comunidade política.

\footnotetext{
${ }^{29}$ ARENDT, Hannah. Sobre a violência. Tradução de André Duarte. Rio de Janeiro: Civilização Brasileira, 2000 , p. 65.

${ }^{30}$ ARENDT, Hannah. 0 que é política? Tradução de Reinaldo Guarany. 10 ed. Rio de Janeiro: Bertrand Brasil, 2012, p. 61-79.

31 ARENDT, Hannah. 0 que é política? Tradução de Reinaldo Guarany. 10 ed. Rio de Janeiro: Bertrand Brasil, 2012, p. 68.

32 Art. $1^{\circ}$, parágrafo único, da Constituição Federal. BRASIL. Constituição Federal. Brasília: Senado Federal, 1988. Disponível: http://www.planalto.gov.br/ccivil_03/constituicao/constituicao.htm. Acesso em: 28 maio 2019.
} 
ISSN 1981-3694

(DOI): $10.5902 / 1981369434534$

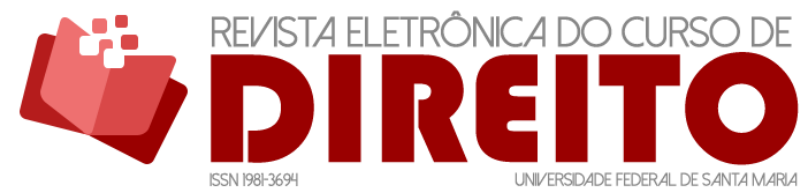

RADICALIZANDO A DEMOCRACIA, REDEFININDO A ESFERA PÚBLICA, REDESENHANDO INSTITUIÇÕES: UM ENSAIO PARA MAIOR PARTICIPAÇÃO POPULAR NA POLÍTICA

KATYA KOZICKI MARIA Helena FonseCA FALler

Eis as premissas que orientarão esse exercício reflexivo: a política como liberdade, como exercício de estar com os outros e estar no mundo, como espaço de expressão de conflitos, diferenças e transformação de antagonismos em agonismos. O poder como capacidade de agir, de determinar, de decidir, de interferir e de construir o mundo que, no caso da política, pertence ao povo e requer desenhos institucionais que permitam o reconhecimento da pluralidade de concepções e modos de vida: esferas públicas múltiplas e plurais, desenhadas para permitir a existência de uma democracia radical.

\section{A DEMOCRACIA RADICAL E A POLÍTICA DEMOCRÁTICA}

O núcleo da ideia de democracia radical de Chantal Mouffe foi exposto anteriormente e, agora, sua compreensão sobre a política democrática será aprofundada. Além disso, John Dewey será agregado à reflexão, com a função de contribuir para o pensamento sobre a democracia radical sob outra perspectiva, que agrega aspectos fundamentais para compreendê-la também como "um modo de vida".

A democracia radical introduz, na filosofia política, um elemento que era considerado marginal: a importância das paixões no espaço político, como uma das motivações que envolvem os indivíduos na sua ação política, ao lado do interesse e da razão. Trata-se de uma proposta de democracia que pensa em uma "nova articulação para os princípios liberais da igualdade e da liberdade". 33

O modelo adversarial proposto por Mouffe entende o debate democrático e a política democrática como um confronto real, são adversários que lutam, mas de acordo com um escopo de regras compartilhadas. Nesse cenário, mesmo que suas posições permaneçam irreconciliáveis, são aceitas como legítimas, porquanto:

A diferença fundamental entre os pontos de vistas “dialógicos" e os pontos de vistas "agonísticos" é que o objetivo deste último é transformar profundamente as relações de poder existentes e estabelecer uma nova hegemonia. É por essa razão que ele pode ser corretamente chamado de "radical". Na verdade, não se trata da política revolucionária de tipo jacobino, mas tampouco a de tipo liberal

33 KOZICKI, Katya. Democracia radical e cidadania: reflexões sobre a igualdade e a diferença no pensamento de Chantal Mouffe. In: FONSECA, Ricardo Marcelo (Org.). Repensando a Teoria do Estado. Belo Horizonte: Fórum, 2004, p. 327-345. 
em que interesses concorrentes se enfrentam em um terreno neutro ou da formação discursiva de um consenso democrático. ${ }^{34}$

Nesses espaços, o poder é colocado em disputa, em debate, permeando várias questões que precisam ser decididas e quem vence o debate e se apropria do poder de decisão determina qual política deve ser adotada e qual deve prevalecer. A questão central, nesse caso, é que aquele que não conquistou o poder de determinação deve permanecer dignamente no "jogo", reconhecido e respeitado em todos os seus direitos, com acesso ao espaço político, de modo que possa buscar a afirmação de suas preferências e a modificação da decisão provisória. 0 político é uma dimensão constitutiva da comunidade. São necessárias, nesse sentido, instituições que permitam o pluralismo e a coexistência de identidades conflituosas.

Os canais políticos legítimos que permitem a expressão e o acolhimento das vozes discordantes são indispensáveis para a concretização da democracia. A transformação do antagonismo em agonismo exige esses canais, que devem ser múltiplos e flexíveis, considerados legítimos e respeitados como espaços autênticos de expressão política, que são levados em consideração na construção do social e das políticas. Do contrário, assumem a aparência de instrumentais para enganar e domesticar o povo ${ }^{35}$.

As instituições democráticas permitem a expressão e a canalização das vontades. Logo, os resultados que oferecem não são, necessariamente, os mais racionais, os melhores e os mais inteligentes, mas são apenas a expressão das vontades que alçaram maior força de impostação no jogo democrático, seja pela quantidade ou pela qualidade. Nesse contexto, o grupo que

34 KOZICKI, Katya. Democracia radical e cidadania: reflexões sobre a igualdade e a diferença no pensamento de Chantal Mouffe. In: FONSECA, Ricardo Marcelo (Org.). Repensando a Teoria do Estado. Belo Horizonte: Fórum, 2004, p. 327-345.

${ }^{35}$ Nesse aspecto, vale a pena referenciar a conexão existente entre Jurgen Habermas e Chantal Mouffe, no que se refere à compreensão de que uma democracia exige uma pluralidade de canais que permitam o acolhimento e expressão da pluralidade de vozes existentes na comunidade política, a partir da aceitação compartilhada das regras do jogo democrático, quais sejam: os princípios éticos-políticos da igualdade e da liberdade para que os antagonismos sejam convertidos em agonismos. Contudo, concebem a construção do debate público de forma diversa. Habermas acredita na construção de uma deliberação racional, fruto de um exercício de debates reflexivos concebidos a partir de condições ideais normativas, nas quais as pessoas se encontram em posições de liberdade e igualdade de expressão. Mouffe, por sua vez, critica essa estrutura de pensamento, uma vez que entende que as condições reais de existência e seus diferentes modos de vida não permitem a instauração das condições ideais e racionais da deliberação, pelo contrário, admite a existência de paixões e afetos como elementos constitutivos do espaço político e compreende que a política reflete a força hegemônica presente na sociedade naquele determinado período histórico. In: HABERMAS, Jurgen. A Ética da Discussão e A Questão da Verdade. 3. ed. São Paulo: WMF Martins Fontes, 2013; CARVALHO, Juliana Bruna Corrêa Lima de. Sobre os Limites da Argumentação Judicial: Ativismo Judicial, Jürgen Habermas e Chantal Mouffe. Revista do Direito Público, Londrina, v.8, n.1, p.9-52, jan./abr.2013. 
ISSN 1981-3694

(DOI): $10.5902 / 1981369434534$

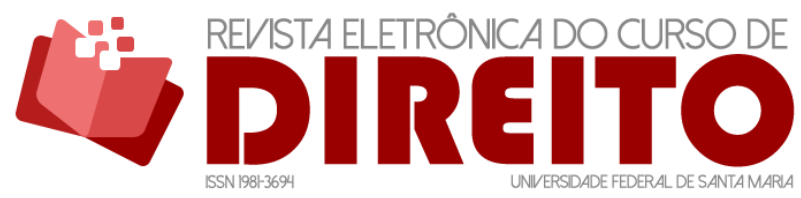

RADICALIZANDO A DEMOCRACIA, REDEFININDO A ESFERA PÚBLICA, REDESENHANDO INSTITUIÇÕES: UM ENSAIO PARA MAIOR PARTICIPAÇÃO POPULAR NA POLÍTICA

KATYA KOZICKI Maria Helena Fonseca Faller

"perde" o jogo não é eliminado ou obrigado a abrir mão de suas próprias convicções ${ }^{36}$. 0 sistema parlamentar é um exemplo claro disso. Não obstante as críticas que recebe, é ainda uma instituição central para as democracias, pois permite a transformação do antagonismo em agonismo.

Uma questão fundamental a ser considerada quando se reflete sobre política democrática no contexto de uma democracia radical, conforme já exposto, é a importância da dimensão afetiva na política e a necessidade de mobilizar as paixões por intermédio dos canais democráticos.

O suposto discurso neutro e racional já deu provas de sua insuficiência, afinal, a política expressa o mundo da vida. A ratio se forma também pela emoção, a razão não é sempre boa, emoção não é sempre descontrole. A paixão move a vida, guia escolhas e aglutina as pessoas em torno de identificações coletivas. Admitir sua existência impõe apenas clarificar algo que sempre existiu e nunca foi assumido, sob a égide de uma crença na existência de uma razão universal pura.

Sob esse pano de fundo, Mouffe chama a atenção para o fato de que, atualmente, muitos antagonismos políticos são formulados em termos de categorias morais. Na esfera da moralidade, os antagonismos não podem se transformar em agonismos e acabam impossibilitando uma análise política adequada. A resposta fica limitada "à construção de um cordão sanitário para pôr em quarentena setores afetados. [...] Democratas não são sempre bons, extrema direita não é sempre do mal". ${ }^{37} 0$ maniqueísmo e a simplificação não são suficientes para explicar o mundo.

A questão não é excluir a moralidade e a ética do espaço político, mas formular os problemas em termos políticos adequados. A ética integra o espaço político e deve balizar o processo de aceitação do conflito, orientando o olhar das pessoas ali envolvidas. É diferente de utilizá-la como instrumental para realizar uma negociação que negue as identidades. Há, nesse caso, a prevalência de um dos lados, mas existe a aceitação ética por parte de quem obteve a hegemonia e por parte de quem terá que aceitá-la.

Os princípios ético-políticos da democracia liberal não são um engodo, mesmo que haja um fosso que os separam do atual estado de coisas. É necessário ter a sutileza e o cuidado para compreender que as tentativas fracassadas de sua concretização não implicam sua negação, mas

\footnotetext{
${ }^{36}$ MOUFFE, Chantal. Sobre o político. Tradução Fernando Santos, São Paulo: WMF Martins Fontes, 2015, p. 21.

${ }^{37}$ MOUFFE, Chantal. Sobre o político. Tradução Fernando Santos, São Paulo: WMF Martins Fontes, 2015, p. 72.
} 
ISSN 1981-3694

(DOI): $10.5902 / 1981369434534$

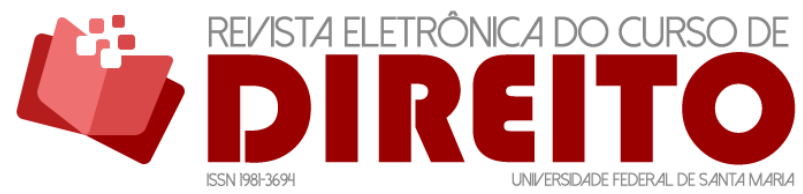

RADICALIZANDO A DEMOCRACIA, REDEFININDO A ESFERA PÚBLICA, REDESENHANDO INSTITUIÇÕES: UM ENSAIO PARA MAIOR PARTICIPAÇÃO POPULAR NA POLÍTICA

KATYA KOZICKI MARIA HELENA FONSECA FALLER

a confirmação de que é imprescindível buscar novos modos de construir a política democrática, pensando-a, também, a partir de desenhos institucionais novos.

John Dewey falou de democracia radical no início do século XX, opondo-se, fortemente, aos regimes totalitários do período. Na introdução a uma de suas obras, Augusto Franco sintetiza a ideia central deste autor: "Só se pode alcançar democracia praticando democracia. A democracia é meio e fim, constituindo-se, portanto, como alternativa de presente e não apenas como modelo utópico de futura sociedade ideal. Não se pode chegar a uma sociedade democrática a não ser por meio do exercício da democracia". ${ }^{38}$

A teoria normativa democrática de Dewey foi chamada de democracia cooperativa, porém ele próprio a denominava de democracia radical e forte, porque a democracia não se refere apenas às instituições políticas, mas, principalmente, a um “modo de vida, baseado em uma aposta nas possibilidades da natureza humana, no homem comum, nas atitudes que os seres humanos revelam em suas mutuas relações, em todos os acontecimentos da vida cotidiana".39

A democracia como modo de vida só pode ser experimentada no interior de sistemas formalmente democráticos, não se podendo usar métodos autocráticos para atingir fins democráticos. Nesse sentido, conforme já dito, o autor deixa clara sua desaprovação aos regimes totalitários do século XX.

Sua ideia de democracia baseia-se na convicção de que os seres humanos comuns podem aprender a se autoconduzir quando imersos em ambientes comunitários que favorecem o exercício coletivo da cooperação, da conexão e empatia recíprocas. Ao tratar sobre o conflito e a dicotomia amigo/inimigo de Schmitt, Dewey propõe que os ambientes democráticos possibilitem a conversão de inimizade em amizade política, no sentido de que se reconheça que o sujeito que pensa diferente pode tornar-se amigo, não obstante a controvérsia manter-se. Sua ideia é que a rivalidade e a competição de ideias podem subsistir, desde que as pessoas cooperem entre si e não objetivem a eliminação do diferente. Assim:

[...] Afastar, ao máximo possível, todo conflito que surgir - e certamente eles surgirão - da atmosfera e meio da força, de violência como um meio de solução e resolvê-lo através da discussão e inteligência significa tratar aqueles que discordam - mesmo profundamente - de nós como aqueles com quem podemos aprender e, na medida do possível, como amigos. Uma fé genuinamente democrática na paz é uma fé na possibilidade de administrar disputas, controvérsias e conflitos como tarefas cooperativas em que ambas as partes

${ }^{38}$ DEWEY, John. Democracia cooperativa: escritos políticos escolhidos de John Dewey (1927-1939). Edição Augusto de Franco e Thamy Pogrebinschi. Porto Alegre: EDIPUCRS, 2008, p. 14.

39 DEWEY, John. Democracia cooperativa: escritos políticos escolhidos de John Dewey (1927-1939). Edição Augusto de Franco e Thamy Pogrebinschi. Porto Alegre: EDIPUCRS, 2008, p. 15. 
ISSN 1981-3694

(DOI): $10.5902 / 1981369434534$

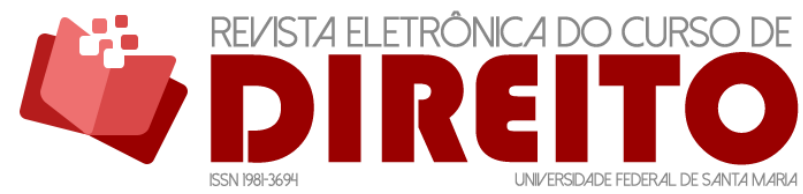

RADICALIZANDO A DEMOCRACIA, REDEFININDO A ESFERA PÚBLICA, REDESENHANDO INSTITUIÇÕES: UM ENSAIO PARA MAIOR PARTICIPAÇÃO POPULAR NA POLÍTICA

KATYA KOZICKI MARIA Helena FonseCA FAller

aprendam dando à outra a chance de se expressar, ao invés de uma parte conquistar pela supressão da outra à força. ${ }^{40}$

É notável a diferença entre o pensamento de Dewey e Mouffe, todavia, os autores “conversam” em suas teorias ao compreenderem que a radicalização da democracia implica, também, aceitação e reconhecimento do diferente, suprimindo a prática e a narrativa da eliminação do inimigo e da diferença.

Nessa conjuntura, Dewey preocupa-se em indicar a existência de uma amizade política entre diferentes. Mouffe, por sua vez, ocupa-se em afirmar a necessidade do pluralismo e da aceitação do conflito como dimensão inerradicável da democracia, propondo que o diferente seja qualificado como o adversário, a ser respeitado e não eliminado. Ainda, os dois autores se conectam em um ponto central de suas teorias: ambos compreendem que os fins socialmente radicais de uma democracia (igualdade e liberdade) podem ser atingidos por intermédio de meios democráticos liberais.

Dewey entende que a democracia como modo de vida deve nortear a vida comunitária, a qual é caracterizada por relações horizontais entre seus membros. Ele não se ocupa em pensar um projeto destinado ao estado-nação e às suas formas de administração política, tampouco, propõe superação ou substituição nesse âmbito. Esse modo de vida se constrói localmente nas comunidades, na afirmação da liberdade em um processo social. Tal liberdade depende de uma atuação comunitária na esfera pública, que exige cooperação. ${ }^{41}$

Esfera pública, para Dewey, é a instância em que se busca, experimentalmente, explorar, processar e resolver problemas de coordenação social. 0 agente político democrático atua nesses espaços, como participante ativo, com consciência da responsabilidade compartilhada que possui e da necessidade de cooperação. ${ }^{42}$

É identificável, no pensamento do autor, uma preparação teórica consistente para se refletir sobre a ideia de redes interligadas que constituem uma esfera pública ampliada para além das dimensões formais do estado-nação. A ideia de democracia radical e forte de Dewey é cooperativa, comunitária, ampla, difusa e catalisadora de experimentos participativos, que proporcionam o desenvolvimento de relações de confiança e cooperação na construção do espaço público.

\footnotetext{
${ }^{40}$ DEWEY, John. Democracia cooperativa: escritos políticos escolhidos de John Dewey (1927-1939). Edição Augusto de Franco e Thamy Pogrebinschi. Porto Alegre: EDIPUCRS, 2008.

41 DEWEY, John. Democracia cooperativa: escritos políticos escolhidos de John Dewey (1927-1939). Edição Augusto de Franco e Thamy Pogrebinschi. Porto Alegre: EDIPUCRS, 2008, p. 20.

42 DEWEY, John. Democracia cooperativa: escritos políticos escolhidos de John Dewey (1927-1939). Edição Augusto de Franco e Thamy Pogrebinschi. Porto Alegre: EDIPUCRS, 2008, p. 21.
} 
Finalmente, é necessário destacar a importância que o autor dedica à dimensão pessoal ao tratar da democracia como modo de vida. Nessa perspectiva, instituições democráticas precisam de sujeitos democráticos que as sustentem, ${ }^{43}$ pois

[...] a democracia é um modo pessoal de vida individual; que ela significa a posse e o uso contínuos de certas atitudes, formando o caráter pessoal e determinando o desejo e a finalidade em todas as relações de vida. Ao invés de pensarmos em nossas próprias disposições e hábitos acomodados a certas instituições, temos de aprender a pensar neles como expressões e extensões das atitudes pessoais dominantes. [...] A democracia como um modelo de vida pessoal e individual [...] confere um novo sentido a velhas idéias. [...] inimigos poderosos da democracia podem ser confrontados com sucesso apenas pela criação de atitudes pessoais nos seres humanos individuais; que podemos superar nossa tendência de pensar que sua defesa pode ser encontrada em meios externos quaisquer, sejam militares ou civis, se eles estiverem separados de atitudes individuais arraigadas a ponto de constituir o caráter pessoal. ${ }^{44}$

Assim, há forte convicção de que a potencialidade humana pode construir a democracia. Palavras como "crença no Homem Comum" e "credo democrático" são recorrentes na teoria da democracia radical de John Dewey. 0 credo democrático consiste na

[...] fé democrática na igualdade humana, a crença que todo ser humano, independente da quantidade ou extensão de seu dom pessoal, tem direito a uma oportunidade igual a todas as outras pessoas de desenvolver os talentos que possui. Crença na capacidade de toda pessoa de conduzir sua própria vida, livre de coerção e imposição pelos outros". ${ }^{45}$

Uma democracia radical, tanto nos termos de Mouffe, como nos termos de Dewey, requer uma política democrática robusta. A partir disso, o que dizer a respeito do silêncio diante das crises e dos regimes pseudodemocráticos instaurados no mundo ocidental? 0 silêncio denota uma crise que guarda raízes na gestação do republicanismo: a concepção unilateral de cidadania

\footnotetext{
43 Roberto Gargarella aborda essa questão, afirmando que de nada adiantam estuturas políticas e instituições com desenhos democráticos sem condições materiais que as sustentem, que se compõem também de sujeitos aptos a assumir esse papel. A experiencia recente da Venezuela parece comprovar essa afirmação: um país com uma Constituição tecida a partir da institucionalização da participação popular e um regime totalitário crescendo sob sua égide. In: GARGARELLA, Roberto. La sala de maquinas de la Constitución: dos siglos de Constitucionalismo en América Latina (1810-2010). Buenos Aires: Katz Editores, 2014, p.361.

44 DEWEY, John. Democracia Criativa: a tarefa diante de nós. In: Democracia Cooperativa: Escritos Políticos de John Dewey (1927-1939). Edição Augusto de Franco e Thamy Pogrebinschi. Porto Alegre: EDIPUCRS, 2008, p. 137-138.

45 DEWEY, John. Democracia Criativa: a tarefa diante de nós. In: Democracia Cooperativa: Escritos Políticos de John Dewey (1927-1939). Edição Augusto de Franco e Thamy Pogrebinschi. Porto Alegre: EDIPUCRS, 2008, p. 137-138.
} 
ISSN 1981-3694

(DOI): $10.5902 / 1981369434534$

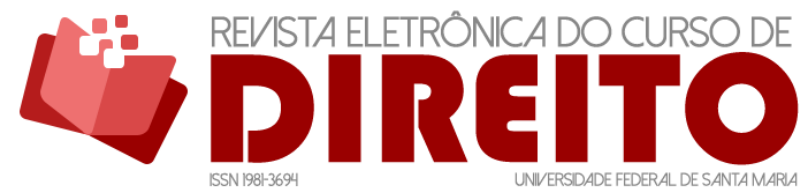

RADICALIZANDO A DEMOCRACIA, REDEFININDO A ESFERA PÚBLICA, REDESENHANDO INSTITUIÇÕES: UM ENSAIO PARA MAIOR PARTICIPAÇÃO POPULAR NA POLITICA

KATYA KOZICKI MARIa Helena FonseCa FAller

refletida em muitas das Constituições ocidentais. Essa concepção se concentra apenas na garantia de direitos e na ampliação desse rol, com vistas a proteger a pessoa contra o arbítrio estatal e também social, desconsiderando a atividade cívica como componente fundamental para o exercício da cidadania.

Assim, a cidadania ganha a posição de instituição básica, mas não há aprofundamento da questão. A concepção democrática de cidadania significa que um cidadão pode exercer seus direitos para promover ou proteger o tipo de governo que depende de sua participação pessoal na resolução das inquietudes comuns. ${ }^{46}$

Essa concepção de cidadania, compreendida como de vertente liberal por Sheldon Wolin, coloca os direitos acima da política, partindo de uma narrativa de proteção em face das maiorias e das paixões delas decorrentes. A política é considerada uma ameaça aos direitos. Assim, desenham-se instituições que visam tão somente controlar os efeitos da política, e não reconstituí-la ou dar-lhe espaço para expressão. ${ }^{47}$

Logicamente que regimes democráticos exigem instituições que estabeleçam mecanismos de proteção aos direitos individuais. Entretanto, é ingênuo tratar tais questões de forma dualista, reduzindo toda a complexidade do contexto democrático à relação de maiorias versus minorias. A política também tem condições de proteger minorias e indivíduos. Não se trata de prerrogativa exclusiva das cortes, até mesmo porque pesquisas indicam que a atuação de algumas delas não é prioritariamente destinada a essas questões. ${ }^{48}$

Nesse sentido, Sheldon Wolin realiza uma reflexão muito importante ao explicar a confusão criada na recorrente identificação da política com a busca por vantagens e defesa de interesses próprios. É necessário, porém, ter clareza de que o cidadão não é uma criatura com vínculos cívicos preexistentes, mas uma pessoa com preferências políticas, pessoais e sexuais que o diferenciam facilmente dos outros. A questão é pensar que o cidadão deve compreender seus interesses e preferências a partir da perspectiva que integra uma comunidade de pessoas e

\footnotetext{
${ }^{46}$ WOLIN, Sheldon. Qué significa la acción revolucionaria hoy. In: MOUFFE, Chantal (et al). Dimensiones de democracia radical: pluralismo, cidadania, comunidade. Buenos Aires: Prometeo Libros, 2012, p. 302304.

47 WOLIN, Sheldon. Qué significa la acción revolucionaria hoy. In: MOUFFE, Chantal (et al). Dimensiones de democracia radical: pluralismo, cidadania, comunidade. Buenos Aires: Prometeo Libros, 2012, p. 302304.

48 Ver, a propósito, resultados de uma pesquisa realizada sobre a natureza das decisões do Supremo Tribunal Federal. In: ARGULHES, Diego Werneck; RIBEIRO, Leandro Molhano. Preferências, Estratégias e Motivações: Pressupostos institucionais de teorias sobre comportamento judicial e sua transposição para o caso brasileiro. Universidade Estadual do Rio de Janeiro. Revista Direito e Práxis. Vol.4, n.02, 2013, p. 85-121.
} 
que essas questões pessoais devem incorporar as decisões, considerando a realidade em sua integralidade. ${ }^{49}$ As paixões constituem o espaço político, assim como os interesses e a razão.

Ainda, Wolin agrega uma questão bastante relevante para o contexto latino americano, permeado pela desigualdade política e social: o fenômeno da despolitização das pessoas mais pobres $^{50}$ que fica ainda mais evidente quando se verificam o silêncio e a apatia em um contexto de crise e desemprego. Historicamente, as pessoas mais pobres são vistas como "párias" sociais e usuários de políticas públicas, tratados pela burocracia estatal como cidadãos de segunda categoria. 0 modo como são geridos os programas sociais tornam essa questão bastante clara. ${ }^{51}$

O que preocupa é a existência de uma forte consciência popular de que a riqueza e o poder econômico traduzem-se em poder político e influência, acompanhada da convicção socialmente difundida - por aqueles que possuem riquezas e poder econômico - de que essa posição injusta e privilegiada não é controlável facilmente. Tal situação difunde a narrativa de impotência e aprofunda a despolitização, não apenas das pessoas mais pobres, mas de modo geral.

Nesse cenário, a nova forma de política democrática proposta por Wolin possibilitaria a criação de novas formas de vida política. Seres políticos não são sujeitos abstratos de direitos, privilégios e imunidades. São, ao contrário, pessoas cuja existência funda-se em um local particular, do qual retiram sua substância e no qual estabelecem suas relações: família, amigos, igreja, trabalho, comunidade, povo, cidade.

${ }^{49}$ WOLIN, Sheldon. Qué significa la acción revolucionaria hoy. In: MOUFFE, Chantal (et al). Dimensiones de democracia radical: pluralismo, cidadania, comunidade. Buenos Aires: Prometeo Libros, 2012, p. 306.

${ }^{50}$ Wolin explica que o problema da cidadania dos mais pobres foi tratada, de forma central, a partir do prisma de que somente é necessário ampliar o rol de direitos econômicos e sociais. De fato, é muito importante. Contudo, a questão não é só essa, visto que os direitos políticos são tão importantes quanto os direitos econômicos. Os recursos para a concretização dos direitos sociais e econômicos são finitos. A ação política é infinita. A capacidade de agir pode transformar questões de modos improváveis. Reduzir a questão da pobreza e da cidadania dos mais pobres à concretização dos direitos sociais e econômicas é desprezar a dimensão política e cívica da cidadania, reduzir as possibilidades dessas pessoas de pensarem e agirem politicamente, participando da construção de novos arranjos políticos e econômicos que implicariam melhoras significativas na distribuição e no acesso a recursos. In: WOLIN, Sheldon. Qué significa la acción revolucionaria hoy. In: MOUFFE, Chantal (et al). Dimensiones de democracia radical: pluralismo, cidadania, comunidade. Buenos Aires: Prometeo Libros, 2012, p. 308

51 "Quienes son pobres, están desempleados o son membros de minorias raciales pueden recibir um trato diferente, un trato que los divide, los hace incapaces de realizar acciones políticas sostenidas. Son el "objetivo" de programas especializados, que de hecho, fragmentan sus vidas. [...] Si la vida de una persona se somete primero a uma faena de burocratas cuyos cuestionarios investigan cada detalle de ella y esa se reorganiza en categorias correspondientes a programas públicos que son el médio de obtener recursos, la persona perde por completo la capacidade como ser politico, incapaz de compreender el sentido de las inquietudes comunes de uma totalidade tan pequena como el vencidario. Eso se debe a que se lo ha privado de la totalidade más elemental de todas: el yo". In: WOLIN, Sheldon. Qué significa la acción revolucionaria hoy. In: MOUFFE, Chantal (et al). Dimensiones de democracia radical: pluralismo, cidadania, comunidade. Buenos Aires: Prometeo Libros, 2012, p. 308. 
São dessas relações que os seres políticos obtêm o poder (simbólico, material e psicológico) que thes permite atuar conjuntamente. Nessa perspectiva, percebe-se que o pensamento de Wolin sobre a política guarda profunda consonância com o pensamento de Hannah Arendt e também de Chantal Mouffe. ${ }^{52}$ Nas suas palavras:

[...] pues el verdadero poder politico involucra no sólo actuar de manera de llevar a cabo câmbios efectivos, sino también la capacidade de recibir poder, de actuar, de cambiar y ser cambiado. Desde uma perspectiva democrática, el poder no es sólo fuerza que se genera; es experiencia, sensibilidad, sabidurla, incluso melancolia obtenidas de las diferentes relaciones y los diferentes círculos dentro de los cuales nos novemos. ${ }^{53}$

A radicalização da democracia e a política democrática assim concebidas não cabem no interior da concepção clássica de esfera pública, adstrita ao contexto do Estado Nação. Exigem instituições com desenhos flexíveis, que possibilitem o desenvolvimento de políticas democráticas nascidas da experiência de sujeitos concretos, a partir de uma sensibilidade atenta às necessidades sociais e individuais. Não basta pensar em teorias normativas da democracia, é imperioso refletir sobre um espaço coerente com a sua concretização. Nesse contexto, a proposta de revisitar a teoria política das esferas públicas, concebendo-as de forma flexível e plurais, é necessária, pois pode servir como a moldura que permitiria o desenvolvimento e a realização (no mundo da vida) de uma democracia radical nos termos colocados até então.

\section{ESFERAS PÚBLICAS PLURAIS PARA UMA DEMOCRACIA RADICAL}

John Keane questiona a velha e hegemônica configuração de uma esfera pública criada por um Estado, ligada a um território específico e mediada por meios de comunicação convencionais (rádio, TV, jornais, livros). ${ }^{54}$ Compreende que, diante do desenvolvimento de múltiplas redes espaciais de comunicação, o ideal de uma esfera pública unificada foi superado,

52 O que é comum aos três autores é pensar a política como espaço de interação e de construção comunitária de sentidos reais, do modo de vida cotidiano, que sustenta a existência dos sujeitos concretos, com seus conflitos, com suas diferenças e com suas identidades individuais e/ou coletivas. Como afirma Arendt, a política pode ou não acontecer entre nós. Ela acontece quando estamos em interação com os outros, interferindo na construção do mundo.

${ }^{53}$ WOLIN, Sheldon. Qué significa la acción revolucionaria hoy. In: MOUFFE, Chantal (et al). Dimensiones de democracia radical: pluralismo, cidadania, comunidade. Buenos Aires: Prometeo Libros, 2012, p. 315.

54 Jurgen Habermas, em sua obra Mudança Estrutural da Esfera Pública, retrata a formação da esfera pública moderna (e burguesa) vinculada profundamente à ação dos meios de comunicação tradicionais da época. In: HABERMAS, Jürgen. Mudança Estrutural da Esfera Pública: investigações quanto a uma categoria da sociedade burguesa. Tradução: Flávio R. Kothe. Rio de Janeiro: Tempo Brasileiro, 2003 
ISSN 1981-3694

(DOI): $10.5902 / 1981369434534$

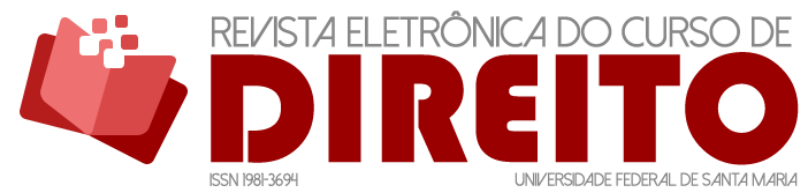

RADICALIZANDO A DEMOCRACIA, REDEFININDO A ESFERA PÚBLICA, REDESENHANDO INSTITUIÇÕES: UM ENSAIO PARA MAIOR PARTICIPAÇÃO POPULAR NA POLÍTICA

KATYA KOZICKI MARIA Helena FonseCA FALleR

assim como a perspectiva republicana da concepção única de bem público. Propõe uma nova visão da vida pública e de seus correlatos (opinião pública e bem público).

O conceito de esfera pública proposto por Keane guarda conexão profunda com a proposta de democracia radical e com a ideia de partilha do poder de decisão, uma vez que reconhece, como espaço público legítimo, as mais variadas expressões, recantos e recessos das sociedades e dos Estados. Sua proposta objetiva rever o papel da esfera pública na teoria política, no quadro de uma república democrática.

Eis sua ideia:

Uma esfera pública é um tipo particular de relação espacial entre duas ou mais pessoas, habitualmente conectadas por determinados meios de comunicação, nos quais irrompem controvérsias não violentas durante períodos de tempo breves ou mais alargados, relativas às relações de poder que operam no quadro do seu meio de interação e/ou no quadro de meios mais alargados de estruturas sociais e políticas, onde os contendores se situam. ${ }^{55}$

Nessa perspectiva, a esfera pública torna-se o meio vital para apontar fraudes, tomar partidos, movimentar o mundo e dessacralizar as relações de poder. Raramente, aparece de forma pura e isolada e se interconecta com outras esferas, possuindo dimensões e heterogeneidade variáveis. Pode ser distinguida entre esferas micropúblicas (interações no âmbito subestatal), mesopúblicas (inclui milhões de pessoas, interações no quadro Estado Nação) e macropúblicas (centenas de milhares pessoas, interações supranacionais e globais). ${ }^{56}$

As esferas micropúblicas, que mais interessam à presente reflexão, delineiam-se nos interstícios, recessos e recantos da sociedade civil. Constituem-se tanto de novos movimentos sociais quanto de círculos de discussão, editoras, igrejas, clínicas, rodas de conversas entre amigos, etc. Ocupam-se de questões e pautas oriundas de necessidades individuais e atuam com envolvimento parcial, focadas no presente, no qual praticam as alterações sociais que buscam para o futuro.

Seus meios organizativos são, por essa razão, valorizados como fins. Constituem redes discretas de pequenos grupos, organizações, iniciativas, contatos locais e amizades, submersas em padrões diários da sociedade civil, caracterizadas pela insistência na solidariedade. Tratamse de laboratórios locais, nos quais são usados meios de comunicação "para questionar e

55 KEANE, John. A sociedade civil. Tradução Mario José Figueiredo. Lisboa: Temas e Debates, 2001, p. 195.

56 KEANE, John. A sociedade civil. Tradução Mario José Figueiredo. Lisboa: Temas e Debates, 2001, p. 195-196. 
ISSN 1981-3694

(DOI): $10.5902 / 1981369434534$

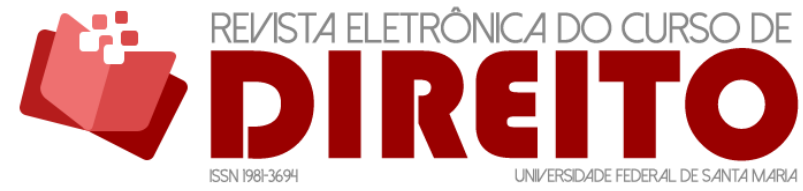

RADICALIZANDO A DEMOCRACIA, REDEFININDO A ESFERA PÚBLICA, REDESENHANDO INSTITUIÇÕES: UM ENSAIO PARA MAIOR PARTICIPAÇÃO POPULAR NA POLÍTICA

KATYA KOZICKI MARIA Helena FonseCA FAller

transformar códigos dominantes da vida de todos os dias”. São espaços públicos em que os elementos da vida de todos os dias são refletidos, misturados e submetidos à crítica, ${ }^{57}$ assim:

Paradoxalmente, porém, estas esferas micropúblicas vão buscar a sua força ao fato de serem sobretudo latentes. Embora pareça que são "privadas", que agem à distância da vida pública oficial, dos partidos políticos e do brilho da publicidade dos meios de comunicação, na verdade exibem todas as características dos esforços públicos de pequenos grupos, cujo desafio à distribuição vigente do poder poderá ser eficaz precisamente porque eles operam nos recantos e recessos não noticiáveis da sociedade civil. ${ }^{58}$

As esferas mesopúblicas, por sua vez, são caracterizadas por milhões de pessoas que agem no quadro do Estado-nação territorial, mediadas por jornais de grande circulação e meios de comunicação eletrônicos. Muitas vezes, são pressionadas pelas esferas micropúblicas. Já as macropúblicassão são constituídas por milhares de pessoas envolvidas em disputas supranacionais e globais de poder, na concentração internacional de empresas de meio de comunicação, anteriormente geridas por empresas nacionais, na posse em cadeia e cruzada de vários meios de comunicação. Expressa-se na cobertura de eventos internacionais que pretendem alcançar audiência mundial no tratamento de controvérsias públicas para além dos Estados-nação.

Um exemplo desse tipo de esfera pode ser visto na Crise da Praça Tiananmen ocorrida na China em 1989. A televisão por satélite influenciou os três planos: nacionais, diplomacias globais e argumentação pública internacional e, quando houve a interrupção da transmissão do conflito via satélite, pela televisão internacional, as tropas chinesas atacaram os estudantes. ${ }^{59}$

A reconfiguração da esfera pública gera controvérsias, especialmente porque, nessa nova perspectiva, há um claro distanciamento das grandes narrativas e das grandes categorias utópicas que marcaram o desenvolvimento da ideia de republicanismo e de espaço público no decorrer do século XIX e XX. Há, também, algum abandono do princípio normativo da busca de um consenso razoável ou de uma comunicação com vistas a obter consensos baseados no melhor argumento. Os discursos das esferas públicas são leigos e se constroem a partir da racionalidade

${ }^{57}$ KEANE, John. A sociedade civil. Tradução Mario José Figueiredo. Lisboa: Temas e Debates, 2001, p. 197.

58 KEANE, John. A sociedade civil. Tradução Mario José Figueiredo. Lisboa: Temas e Debates, 2001, p. 198.

${ }^{59}$ KEANE, John. A sociedade civil. Tradução Mario José Figueiredo. Lisboa: Temas e Debates, 2001, p. 200-205. 
ISSN 1981-3694

(DOI): 10.5902/1981369434534

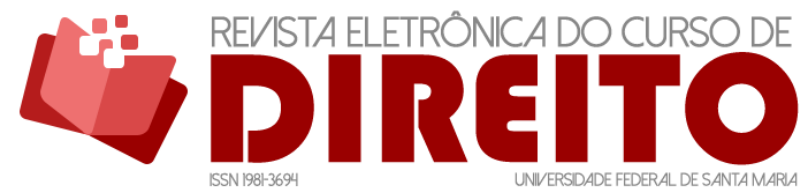

RADICALIZANDO A DEMOCRACIA, REDEFININDO A ESFERA PÚBLICA, REDESENHANDO INSTITUIÇÕES: UM ENSAIO PARA MAIOR PARTICIPAÇÃO POPULAR NA POLÍTICA

KATYA KOZICKI MARIA HELENA FONSECA FALLER

e das emoções que permeiam a vida cotidiana, ${ }^{60}$ portanto, são espaços democráticos de debates, em que as pessoas podem filtrar suas concepções e preconceitos e se colocarem (e recolocarem) no processo de construção do coletivo a partir de um autêntico "face a face" com o outro.

A partir da proposta de reconfiguração de esfera pública, John Keane compreende a democracia como forma pluralista, que abarca variados tipos de comunicação e debates públicos, possibilitando que grupos e indivíduos exprimam, abertamente, sua solidariedade às diversas formas de vida.

Propõe um abandono dos ideais trans-históricos e das verdades definitivas e afirma que não há um critério para determinar qual tipo de controvérsia pública é preferível. Para ele, a democracia saudável é aquela em que prosperam diversos modos de esferas públicas, sem que nenhuma delas detenha o monopólio das discussões acerca da distribuição do poder. Há oposição clara ao ideal de esfera pública única, inserido no âmbito do republicanismo, que corre o risco de esvaziar essa esfera e transformá-la em uma utopia irrealizável. Por suas palavras:

Nesta perspectiva, a proliferação de mosaicos de esferas públicas com dimensões diversas devia ser bem recebida e reforçada, na prática, através da luta política, das leis, do dinheiro e das formas melhoradas de comunicação. Exatamente por causa de sua capacidade de controlar o exercício do poder a partir de uma variedade de locais, no quadro do Estado e das instituições da sociedade civil, as esferas públicas garantem que ninguém "é dono" do poder e fazem aumentar a probabilidade de o seu exercício se tornar, em toda a parte, mais controlável por aqueles que, direta ou indiretamente, ele afeta. ${ }^{61}$

Keane, assim como Dewey, ${ }^{62}$ desenvolve a ideia da construção de esferas que se interligam e se comunicam. 0 autor chama essa proposta de modularização e acredita que a prática da proliferação de redes possibilita que as esferas não se reifiquem, proporcionando partilha de poder. Desse modo, sua ideia central é apresentar uma teoria que revisite a teoria

\footnotetext{
${ }^{60}$ Para aprofundar essas categorias, ver: RAWLS, John. Uma teoria de justiça. Tradução de Almiro Pisetta e Lenita Maria Rímoli Esteves. São Paulo: Martins Fontes, 2002; HABERMAS, Jurgen. A inclusão do outro: estudos de teoria política. Tradução de George Sperber, Paulo Soethe, Milton C. Mota. 2. ed. São Paulo: Loyola, 2004, p. 310-337.

61 KEANE, John. A sociedade civil. Tradução Mario José Figueiredo. Lisboa: Temas e Debates, 2001, p. 215.

62 Dewey trabalhava com uma ideia de rede (sem nominar desse modo) ao conceber as iniciativas democráticas locais como protagonistas de uma democracia cooperativa, a qual interligava todas essas dimensões comunitárias, de modo fluido e flexível, priorizando a autonomia local e o dinamismo democrático e plural. In: DEWEY, John. Democracia cooperativa: escritos políticos escolhidos de John Dewey (1927-1939). Edição Augusto de Franco e Thamy Pogrebinschi. Porto Alegre: EDIPUCRS, 2008, p. 19.
} 
da sociedade civil e da esfera pública, abandonando, para o bem da democracia, a compreensão da vida pública como uma esfera pública unificada. ${ }^{63}$

Essas grandes dicotomias e construções teóricas foram necessárias para explicar o mundo moderno durante determinado período histórico: estado, sociedade política, sociedade civil, esfera pública, esfera privada. Nesse sentido, é ingênuo pensar que são categorias superadas e que devem ser abandonadas, visto que a ideia não é essa, mas compreendê-las a partir das inter-relações complexas e fluidas existentes no mundo de hoje. A democracia nas sociedades complexas exige um novo olhar teórico, novos tipos de ação e novos desenhos institucionais, de maneira experimental e desafiadora.

\section{DESENHOS INSTITUCIONAIS DEMOCRÁTICOS}

Em vários momentos deste artigo, tornou-se evidente a necessidade de pensar acerca de instituições democráticas que permitam a transformação do antagonismo em agonismo e possibilitem a expressão de uma cidadania pautada pela ação cívica, capaz de proporcionar a expressão política como liberdade.

Não bastam teorias normativas democráticas, não basta uma constituição com amplo rol de direitos conquistados, ${ }^{64}$ todavia, a organização da vida política deve permitir acessibilidade à participação popular. E não só. A criação de instituições democráticas que favoreçam essa participação torna-se inócua se o desenho institucional não permite que as decisões e deliberações realizadas nesses espaços condicionem, efetivamente, a criação das políticas.

A deliberação pública e democrática está intimamente relacionada ao desenho institucional, o qual deve favorecer a articulação entre debate e participação pública nas decisões políticas. Segundo Olsen, ${ }^{65}$ o desenho institucional consiste na "intervenção intencional e deliberada que consegue estabelecer novas estruturas e processos institucionais, ou

${ }^{63}$ KEANE, John. A sociedade civil. Tradução Mario José Figueiredo. Lisboa: Temas e Debates, 2001, p. 215.

64 Roberto Gargarella afirma que não bastam Constituições com amplo rol de direitos fundamentais assegurados se a sua sala de máquinas não permite a concretização desses direitos. Organização do poder fortemente centralizada e vertical, instituições democráticas existentes sem poder de decidir e implementar suas decisões denotam que a sala de máquinas da Constituição permanece intocada, pois é nela que devem ocorrer as principais mudanças para que haja a consolidação dos regimes democráticos constitucionais. In: GARGARELLA, Roberto. La sala de maquinas de la Constitución: dos siglos de Constitucionalismo en América Latina (1810-2010). Buenos Aires: Katz Editores, 2014.

65 OLSEN, Johan P. Desenho institucional em contextos democráticos. In: CUNHA, Eleonora Schettini M; THEODORO, Hildelano Delanusse. (Orgs). Desenho institucional, democracia e participação: conexões teóricas e possibilidades analíticas. [Local]: D`Placido Editora, 2014, p. 12. 
ISSN 1981-3694

(DOI): $10.5902 / 1981369434534$

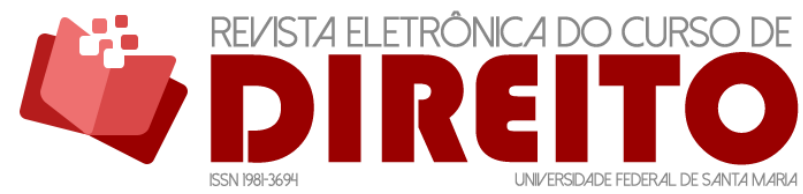

RADICALIZANDO A DEMOCRACIA, REDEFININDO A ESFERA PÚBLICA, REDESENHANDO INSTITUIÇÕES: UM ENSAIO PARA MAIOR PARTICIPAÇÃO POPULAR NA POLÍTICA

KATYA KOZICKI MARIA HELENA FONSECA FALLER

reorganizar as existentes, conseguindo assim resultados pretendidos e melhorias". Os desenhos podem ser de políticas, mecanismos ou sistemas. ${ }^{66}$

A maior parte dos autores que tratam sobre desenhos institucionais destaca a intencionalidade como um elemento essencial: princípios, valores e expectativas orientam a estrutura do desenho, ou seja, os desenhos são concebidos com a finalidade de intervir na realidade política para gerar determinados resultados políticos, portanto, não são obras do acaso.

As circunstâncias e os valores inscritos em determinado contexto social motivarão e orientarão a construção do desenho, logo, não se deve perder de vista a experiência acumulada, que, certamente, influenciará as novas concepções institucionais. Entretanto, essa influência deve ser precedida de capacidade reflexiva para que a correção de arestas e as modificações necessárias sejam realizadas de forma consciente, ${ }^{67}$ uma vez que reproduzir, somente, valores e modelos é tarefa fácil.

Dryzek $^{68}$ chama a atenção para a pluralidade de valores e vozes que permeiam as sociedades contemporâneas, as narrativas que os sustentam e o tom das conversações democráticas que daí decorrem. Nesse sentido, a reflexão acerca das narrativas que permeiam as discussões sobre democracia e instituições políticas é importante para detectar que tipo de mudança de paradigma deve-se operar, com vistas a reconfigurar o diálogo entre as instituições, bem como entre estas e as comunidades em que estão inseridas. A ideia de mudança institucional sugere a possibilidade de realizar "redesenhos institucionais", o que indica que o desenho, necessariamente, não se encerra na medida em que a instituição é implementada. ${ }^{69}$

${ }^{66}$ CUNHA, Eleonora Schettini M. Desenho Institucional, participação e deliberação democráticas. In: CUNHA, Eleonora Schettini M; THEODORO, Hildelano Delanusse. (Orgs). Desenho institucional, democracia e participação: conexões teóricas e possibilidades analíticas. [Local]: D`Placido Editora, 2014, p. 03.

${ }^{67}$ CUNHA, Eleonora Schettini M. Desenho Institucional, participação e deliberação democráticas. In: CUNHA, Eleonora Schettini M; THEODORO, Hildelano Delanusse. (Orgs). Desenho institucional, democracia e participação: conexões teóricas e possibilidades analíticas. [Local]: D Placido Editora, 2014, p. 05.

68 DRYZEK, John S. The Informal Logic of Institutional Design. In: GOODIN, R.E (ed). The theory of Institutional Design. Cambridge: Cambridge University Press, 1996, p. 103-125. Disponível em: http: / / www.google. com.br/url?sa=t\&rct=j\&q=\&tesrc=s\&source=web\&cd=3\&cad=rja\&uact=8\&ved=0ahUKEw iNsKyK69bVAhUKG5AKHctsCoQQFggzMAl\&url=http\%3A\%2F\%2Fjournal-

dl.com\%2Fdownloadpdf\%2F591088453fbb6e13743faf58\&usg=AFQjCNGtVemlxKrTtVti1semyRul-cbjKA. Acesso em: 28 maio 2019.

${ }^{69}$ CUNHA, Eleonora Schettini M. Desenho Institucional, participação e deliberação democráticas. In: CUNHA, Eleonora Schettini M; THEODORO, Hildelano Delanusse. (Orgs). Desenho institucional, democracia e participação: conexões teóricas e possibilidades analíticas. [Local]: D`Placido Editora, 2014, p. 07. 
ISSN 1981-3694

(DOI): $10.5902 / 1981369434534$

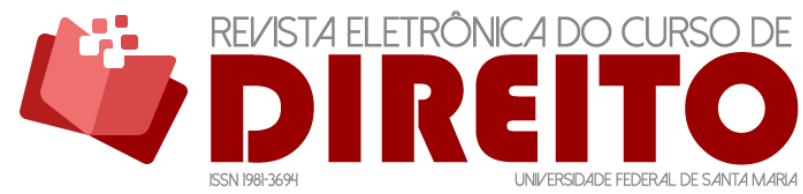

RADICALIZANDO A DEMOCRACIA, REDEFININDO A ESFERA PÚBLICA, REDESENHANDO INSTITUIÇÕES: UM ENSAIO PARA MAIOR PARTICIPAÇÃO POPULAR NA POLITICA

KATYA KOZICKI MARIA HELENA FONSECA FALLER

Nesse sentido, arranjos institucionais democráticos são aqueles que asseguram a autorização para o exercício do poder político, a partir de decisões coletivas dos cidadãos, uma vez que são estes os titulares dos poderes a serem exercidos. ${ }^{70} \mathrm{Na}$ maior parte das democracias modernas, o estado ocupa lugar fundamental nas instituições políticas, uma vez que sua centralidade foi forjada em consonância com o processo de institucionalização do poder político. $^{71}$

Com a chegada do século XX, a sociedade civil passou a ser compreendida como um ator importante na construção da política, contudo, é importantíssimo evidenciar que a participação política não se restringe à relação entre estado e sociedade civil, mas se trata de um componente essencial da construção do espaço político e público que, hoje, realiza-se de modo dinâmico e heterogêneo em ambientes externos à política formal. Coletivos, grupos comunitários e rodas de conversa são exemplos dos inúmeros espaços políticos que realizam importante papel na construção democrática, conforme alertou John Keane.

Ainda, é preciso pensar a participação democrática para além de uma narrativa mítica, que vislumbra o estado como uma ação necessariamente negativa e independente da sociedade civil. Veja: o estado está situado no mesmo contexto histórico-cultural da sociedade e não possui uma mentalidade e uma ratio independente desta.

O que deve ocupar, de maneira central, a reflexão e a práxis é a hipótese de que democracias são assentadas na premissa de autogoverno e isso deve ser concretizado a partir de instituições. Nesse sentido, deve-se pensar e criar instituições que possibilitem a expressão dos cidadãos para além do voto, com a construção de espaços em que os conflitos possam ser acolhidos, expostos e canalizados, locais em que interesses de grupos - quando legítimos -, se tornem políticas. ${ }^{72}$

Os desenhos constitucionais das democracias são concebidos, em sua maioria, para contemplar grandes participações em processos históricos de impacto. A questão é que a política se constrói no cotidiano e seu substrato, que sustenta grandes instituições, é erguido a partir de

\footnotetext{
${ }^{70}$ OLSEN, Johan P. Desenho institucional em contextos democráticos. In: CUNHA, Eleonora Schettini M; THEODORO, Hildelano Delanusse. (Orgs). Desenho institucional, democracia e participação: conexões teóricas e possibilidades analíticas. D Placido Editora, 2014, p. 03.

71 CUNHA, Eleonora Schettini M. Desenho Institucional, participação e deliberação democráticas. In: CUNHA, Eleonora Schettini M; THEODORO, Hildelano Delanusse. (Orgs). Desenho institucional, democracia e participação: conexões teóricas e possibilidades analíticas. [Local]: D`Placido Editora, 2014, p. 09.

72 PERUZZOTTI, Enrique E SMULVITZ, Catalina. Social accountability: an introduction. In: Enforcing the rule of law: social accountability in the new latin american democracies. [Local]: University of Pittsburgh Press, 2006, p. 10.
} 
ISSN 1981-3694

(DOI): $10.5902 / 1981369434534$

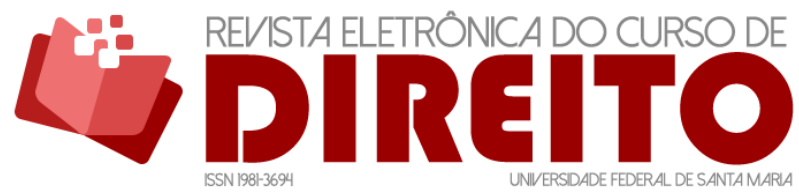

RADICALIZANDO A DEMOCRACIA, REDEFININDO A ESFERA PÚBLICA, REDESENHANDO INSTITUIÇÕES: UM ENSAIO PARA MAIOR PARTICIPAÇÃO POPULAR NA POLÍTICA

KATYA KOZICKI MARIA HELENA FonseCA FALLER

modos de vida democráticos. Do contrário, remanescem discursos, narrativas e instituições aparentemente democráticas, mas conjugadas com práticas arbitrárias - por que não dizer autoritárias - e altamente hierarquizadas. A questão é que as decisões geradas nesses espaços atingem um amplo espectro social, mas vivenciam democracias de fachadas.

Por todas essas questões, a ideia central é desenhar e conceber instituições que possibilitem a participação em pequena escala, dialogando com questões de grande escala e estabelecendo mecanismos que tornem essas deliberações e decisões vinculativas. Aqui, reside o ponto fulcral: abordar a questão dos espaços democráticos de pequena escala a partir da perspectiva dos desenhos institucionais. Não basta reconhecer o caráter democrático dessas iniciativas locais, é necessário dar-lhes voz e proporcionar instrumentos capazes de permitir que suas deliberações influenciem e condicionem a política macro e suas grandes decisões.

Para Barber, ${ }^{73}$ essas inovações institucionais viabilizam uma democracia forte, uma vez que o debate e a decisão política ocorrem em várias esferas e escalas interligadas, as quais permitem a expressão dos conflitos e produzem cooperação e reconhecimento. Na perspectiva de Mouffe, transformam antagonismo em agonismo e pautam-se por valores irrenunciáveis e fundamentais da democracia (liberdade, igualdade e fraternidade).

Nesse aspecto, é importante pensar que as decisões e debates não são, necessariamente, marcados por interesses públicos e gerais e por noções de bem comum abstratas e afastadas da realidade das pessoas. Pelo contrário, são pautados por afetos e paixões, pela vida de todos os dias. Nos dias atuais, conforme atenta Maffesoli, ${ }^{74}$ a mentalidade é constituída por elementos presentes no cotidiano das pessoas, por necessidades e questões que as envolvem vitalmente e ideologicamente.

Isso pode ser bom ou pode ser mau. Na dimensão intersubjetiva, pode-se qualificar ou desqualificar as demandas e as exigências das pessoas e comunidades como positivas ou negativas, respectivamente. É necessário desprender-se da ilusão de que a razão do sujeito é o paramento central para a qualificação moral de determinada questão ou decisão, porquanto é no espaço com os outros, no "face a face" cotidiano, na escuta e no conhecimento recíprocos, promovidos pelo debate público, que deverá ser verificada a decisão sobre o que deve ser bom ou deve ser ruim para determinado âmbito da vida pública. É claro que é possível garantir a melhor decisão, mas, certamente, é um ponto de partida para uma política democrática.

\footnotetext{
${ }^{73}$ BARBER, Benjamin R. Strong Democracy: Participatory Politics for a New Age. Berkeley: University of California Press, 1984, p. 11

${ }^{74}$ MAFFESOLI, Michel, A parte do diabo: resumo da subversão pós-moderna. Tradução de Clóvis Marques. Rio de Janeiro: Record, 2004, p. 61.
} 
ISSN 1981-3694

(DOI): $10.5902 / 1981369434534$

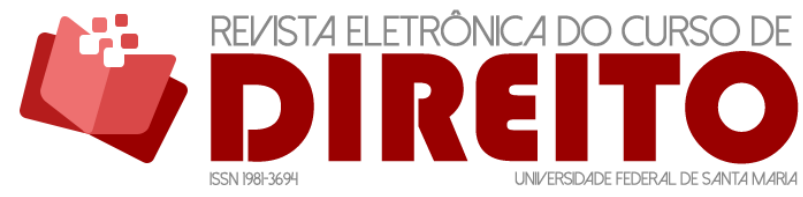

RADICALIZANDO A DEMOCRACIA, REDEFININDO A ESFERA PÚBLICA, REDESENHANDO INSTITUIÇÕES: UM ENSAIO PARA MAIOR PARTICIPAÇÃO POPULAR NA POLÍTICA

KATYA KOZICKI MARIA HELENA FONSECA FALLER

Fica claro, nesse contexto, que o conflito é indissociável da condição democrática. 0 que precisa ser feito é fornecer espaço e tratamento, reconhecê-lo e assumi-lo, caso contrário, o resultado é a violência. As consequências estão disponíveis a qualquer observador minimamente sensível, conforme exemplificado anteriormente.

Nas democracias contemporâneas, a governança toma lugar em redes de políticas policêntricas, de atores públicos e privados. As políticas democráticas, concebidas dentro dessa perspectiva, são ordens mistas, que funcionam à base do equilíbrio (ou desequilíbrio) entre instituições com diferentes preocupações (lógicas, histórias, dinâmicas e recursos), que se desenvolvem em interação e como reação umas às outras. ${ }^{75}$

Para criar instituições políticas, ou modificar as já existentes, são necessários atores políticos comprometidos com a causa e imprescindíveis narrativas e discursos sociais que, de algum modo, legitimem essas mudanças ou criações, ${ }^{76}$ conforme já trazido por Dryzek. Por isso, a importância de pensar a democracia como "modo de vida" a partir do pensamento de John Dewey.

É preciso que essas novas instituições aconteçam, existam e guardem consonância com os modos de vida existentes, para além de suas regras formais. Deve-se refletir sobre o tipo de mudança institucional possível no contexto democrático brasileiro. ${ }^{77}$ Isso é difícil, sem dúvidas, mas não pode, em hipótese alguma, desencorajar a pesquisa e a reflexão, até porque há, no Brasil, experiências reveladoras de potencialidades democráticas ainda a serem aprofundadas ${ }^{78}$.

75 O MAFFESOLI, Michel, A parte do diabo: resumo da subversão pós-moderna. Tradução de Clóvis Marques. Rio de Janeiro: Record, 2004, p. 21.

${ }^{76}$ BAGGIA, Francesca. Estabilidade e mudança das instituições políticas: algumas reflexões sobre dilemas e desafios do desenho institucional num contexto democrático. In: CUNHA, Eleonora Schettini M; THEODORO, Hildelano Delanusse. (Orgs). Desenho institucional, democracia e participação: conexões teóricas e possibilidades analíticas. [Local]: D`Placido Editora, 2014, p. 28.

77 BAGGIA, Francesca. Estabilidade e mudança das instituições políticas: algumas reflexões sobre dilemas e desafios do desenho institucional num contexto democrático. In: CUNHA, Eleonora Schettini M; THEODORO, Hildelano Delanusse. (Orgs). Desenho institucional, democracia e participação: conexões teóricas e possibilidades analíticas. [Local]: D`Placido Editora, 2014, p. 11.

780 projeto de pesquisa Lattino, coordenado por Tamy Pogrebinschi, no Departamento Democracia e Democratização do WZB Berlin Social Science Center e financiado pelo Open Society Foundations, reúne uma base de dados completa sobre as inovações democráticas produzidas em 18 países da América Latina, durante os anos de 1990 a 2016. Registrou, no Brasil, 277 tipos de inovações democráticas, que corresponde à soma de diferentes desenhos institucionais de participação cidadã no país. Cada desenho institucional é contado somente uma vez, independentemente da quantidade de vezes em que ele foi replicado e se ele se espalhou ou não. 0 banco de dados é composto por todos os casos que a equipe de pesquisa conseguiu encontrar em cada país até chegar ao esgotamento de dados. In: Pogrebinschi, Thamy. (2017). LATINNO Dataset. Berlin: WZB. Disponível em: https://www.latinno.net/pt/country/brazil/. Acesso em: 28 abr. 2019. 
ISSN 1981-3694

(DOI): $10.5902 / 1981369434534$

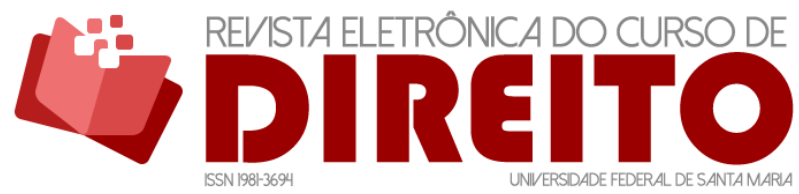

RADICALIZANDO A DEMOCRACIA, REDEFININDO A ESFERA PÚBLICA, REDESENHANDO INSTITUIÇÕES: UM ENSAIO PARA MAIOR PARTICIPAÇÃO POPULAR NA POLÍTICA

KATYA KOZICKI MaRia Helena FonseCa Faller

Basta pensar, a partir de Olsen $^{79}$, que um novo desenho institucional pode dar continuidade a um processo mais amplo, com a criação de uma direção coerente de mudança ao longo do tempo, por intermédio de pequenas mudanças, as quais compõem um projeto de longo prazo. Nas palavras de Biaggia, "a ideia de que mudanças importantes podem ocorrer através de um caminho coerente de pequenas mudanças parece particularmente interessante para se pensar os desafios que o Brasil deverá enfrentar para tentar responder as demandas por reformas políticas". ${ }^{80}$

Mudanças institucionais em democracias estabelecidas partem, de modo geral, de iniciativas de pequena escala, no interior do sistema consolidado, justamente por conseguirem manter-se e desenvolver-se, mesmo se imersas em narrativas dominantes. São incrementais, lentas, graduais e guardam certa coerência com a ordem existente. Acontecimentos menos excepcionais também podem favorecer mudanças institucionais importantes, uma vez que atingem de algum modo as relações de poder no interior do sistema político.

Desenhos institucionais não são neutros, assim, a questão é pensá-los em um contexto radicalmente democrático, para favorecer o desenvolvimento do político e da expressão dos conflitos, de modo que a decisão hegemônica tomada nesse âmbito de disputa de argumentos e de poder seja resultado de um processo profundo de liberdade de expressão e de impostação em que os antagonismos se transformem em agonismos e o adversário/diferente permanece vivo e íntegro para continuar a buscar a realização daquilo que entende por sua política e por seus valores prioritários.

\section{CONCLUSÃO}

A opção por iniciar essa reflexão com o conceito de política de Hannah Arendt ao lado da perspectiva de Chantal Mouffe tinha como objetivo estabelecer a premissa teórica de que a ideia da política como liberdade não é irreconciliável com sua compreensão como espaço de conflito e antagonismo. A proposta consistiu em pensar a política como liberdade de irromper,

79 OLSEN, Johan P. Desenho institucional em contextos democráticos. In: CUNHA, Eleonora Schettini M; THEODORO, Hildelano Delanusse. (Orgs). Desenho institucional, democracia e participação: conexões teóricas e possibilidades analíticas. [Local]: D`Placido Editora, 2014, p. 22.

${ }^{80}$ BAGGIA, Francesca. Estabilidade e mudança das instituições políticas: algumas reflexões sobre dilemas e desafios do desenho institucional num contexto democrático. In: CUNHA, Eleonora Schettini M; THEODORO, Hildelano Delanusse. (Orgs). Desenho institucional, democracia e participação: conexões teóricas e possibilidades analíticas. [Local]: D`Placido Editora, 2014, p. 17. 
ISSN 1981-3694

(DOI): $10.5902 / 1981369434534$

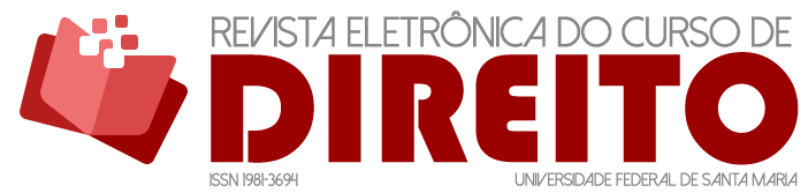

RADICALIZANDO A DEMOCRACIA, REDEFININDO A ESFERA PÚBLICA, REDESENHANDO INSTITUIÇÕES: UM ENSAIO PARA MAIOR PARTICIPAÇÃO POPULAR NA POLÍTICA

KATYA KOZICKI MaRIa Helena FonseCa Faller

de mudar, de interromper, de começar de novo, sob a perspectiva que é o espaço adequado para a expressão do conflito e do antagonismo.

A partir dessa perspectiva, a liberdade é desprendida de uma conotação metafísica, de um a priori e passa a ser compreendida como uma condição real, realizada, justamente, pela existência de espaços públicos plurais que permitem a todos e a cada um a possibilidade de expressar suas necessidades, seus objetivos e projetos de vida, pessoais e/ou coletivos. Nestes espaços, os conflitos são reconhecidos e tratados, sem dissimulá-los em políticas frágeis de consenso. Desenhos institucionais radicalmente democráticos permitem a transformação destes antagonismos em agonismos, permitindo ao diferente - adversário - reconhecimento, dignidade e integridade, de modo que possa continuar a postular e a lutar por sua hegemonia e por seus projetos. Tornar possível a conversão de antagonismos em agonismos exige a multiplicação de espaços públicos de construção da política. As sociedades plurais e complexas contemporâneas exigem a multiplicação de espaços públicos que reconheçam e acolham suas demandas de existência, mesmo que se tornem demandas vencidas.

Em uma democracia radical, o acordo acerca de seus valores políticos-éticos fundamentais - igualdade e liberdade - torna-se motor de conflitos constantes, uma vez que há forte divergência sobre que tipo de práticas esses princípios deveriam exigir e quais prioridades devem ser assumidas. A democracia é um projeto em aberto, pois seus ideais são difíceis de alcançar na prática e nenhum governo jamais chegou perto da visão democrática. Levada a sério, induziria mudança considerável, mesmo nas democracias mais desenvolvidas. ${ }^{81}$

Nesse sentido, a ampliação da esfera pública para as dimensões locais, conectadas com âmbitos nacionais e globais, por meio de instituições desenhadas democraticamente para este fim, permitiria identificar a complexidade que permeia as questões de poder, dos direitos e do político, possibilitando que grupos e pessoas possam participar dos processos decisórios que os afetam. Entende-se que esse tipo de prática ampliaria as hipóteses de concretização da liberdade e da igualdade, pensadas como dimensões da democracia constitucional, em que todas as pessoas possuem a mesma dignidade moral e possuem igual direito de intervir nos assuntos que afetam a sua comunidade, reconhecendo-se como pares, independentemente de posição política e de escolhas morais, portanto, como adversários, e não inimigos, na busca por um consenso conflituoso.

81 OLSEN, Johan P. Desenho institucional em contextos democráticos. In: CUNHA, Eleonora Schettini M; THEODORO, Hildelano Delanusse. (Orgs). Desenho institucional, democracia e participação: conexões teóricas e possibilidades analíticas. D P Placido Editora, 2014, p. 07. 
ISSN 1981-3694

(DOI): $10.5902 / 1981369434534$

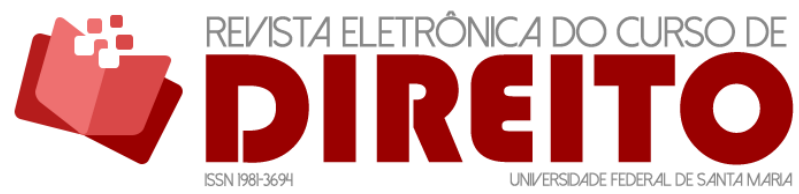

RADICALIZANDO A DEMOCRACIA, REDEFININDO A ESFERA PÚBLICA, REDESENHANDO INSTITUIÇÕES: UM ENSAIO PARA MAIOR PARTICIPAÇÃO POPULAR NA POLÍTICA

KATYA KOZICKI MARIA Helena FonseCA FAller

Conclui-se, a partir da articulação teórica desenvolvida neste artigo, que a radicalização democrática comporta e favorece a noção de esfera(s) pública(s) plural(is), com instituições desenhadas democraticamente de forma a potencializar um maior acesso ao poder político pelo povo, aumentando e qualificando a participação popular na construção das democracias.

No Brasil, os milagres esperados da capacidade de ação do homem na política podem ser identificados nos mais variados modos de experimentalismo democrático presentes nas instituições criadas com a promulgação da Constituição de 1988. Percebe-se, justamente pela ausência de dados atualizados sobre efetividade e resultados dessas instituições, que ocorreu, nos últimos anos, certo esvaziamento de suas atuações e pautas. ${ }^{82}$

0 atual estado de coisas do país indica uma forte fragilização da democracia e do regime constitucional em vigor. Os absurdos em curso não podem retirar a capacidade criativa da liberdade de agir e de mudar, de iniciar um novo processo, com todos os conflitos vitais e necessários para a existência de uma política democrática, dirigindo todos os esforços teóricos e práticos, com o intuito de melhorar, reconstruir e construir instituições políticas radicalmente democráticas, com desenhos institucionais cuidadosamente pensados para esse objetivo.

\section{REFERÊNCIAS}

ARGULHES, Diego Werneck; RIBEIRO, Leandro Molhano. Preferências, Estratégias e Motivações: Pressupostos institucionais de teorias sobre comportamento judicial e sua transposição para o caso brasileiro. Universidade Estadual do Rio de Janeiro. Revista Direito e Práxis. Vol.4, n.02, 2013, p. 85-121.

ARENDT, Hannah. A condição humana. Tradução de Roberto Raposo. 10. ed. Rio de Janeiro: Forense Universitária, 2003.

ARENDT, Hannah. O que é política? Tradução de Reinaldo Guarany. 10.ed. Rio de Janeiro: Bertrand Brasil, 2012.

ARENDT, Hannah. Sobre a violência. Tradução de André Duarte. Rio de Janeiro: Civilização Brasileira, 2000.

BARBER, Benjamin R. Strong Democracy: Participatory Politics for a New Age. Berkeley: University of California Press, 1984.

82 As publicações mais recentes acerca dos índices de participação social nas instituições e sobre a efetividade das instituições participativas no Brasil datam o ano de 2015 ou ainda anos anteriores, dependendo do tema. A propósito, verificar: http://www.ipea.gov.br/participacao/ 
BAGGIA, Francesca. Estabilidade e mudança das instituições políticas: algumas reflexões sobre dilemas e desafios do desenho institucional num contexto democrático. In: CUNHA, Eleonora Schettini M; THEODORO, Hildelano Delanusse. (Orgs). Desenho institucional, democracia e participação: conexões teóricas e possibilidades analíticas. D Placido Editora, 2014.

BRASIL. Constituição Federal. Brasília: Senado Federal, 1988. Disponível: http://www.planalto.gov.br/ccivil_03/constituicao/constituicao.htm. Acesso em: 28 maio 2019.

BRASIL. Decreto-Lei 8243/2014. In: Diário Oficial da República Federativa do Brasil, Brasília, DF, 23 maio 2014. Disponível: http://www.planalto.gov.br/ccivil_03/_Ato20112014/2014/Decreto/D8243.htm. Acesso em: 28 maio 2019.

CARVALHO, Juliana Bruna Corrêa Lima de. Sobre os Limites da Argumentação Judicial: Ativismo Judicial, Jürgen Habermas e Chantal Mouffe. Revista do Direito Público, Londrina, v.8, n.1, p.952, jan./abr.2013.

CUNHA, Eleonora Schettini M. Desenho Institucional, participação e deliberação democráticas. In: CUNHA, Eleonora Schettini M; THEODORO, Hildelano Delanusse. (Orgs). Desenho institucional, democracia e participação: conexões teóricas e possibilidades analíticas. [Local]: D`Placido Editora, 2014.

DEWEY, John. Democracia cooperativa: escritos políticos escolhidos de John Dewey (19271939). Edição Augusto de Franco e Thamy Pogrebinschi. Porto Alegre: EDIPUCRS, 2008.

DRYZEK, John S. The Informal Logic of Institutional Design. In: GOODIN, R.E (ed). The theory of Institutional Design. Cambridge: Cambridge University Press, 1996, p. 103-125. Disponível em http: / / www.google.com.br/url?sa=t\&rct=j\&qq=\&esrc=s\&source=web\&cd=3\&cad=rja\&uact=8\&ved =0ahUKEwiNsKyK69bVAhUKG5AKHctsCoQQFggzMAl\&url=http\%3A\%2F\%2Fjournaldl.com\%2Fdownloadpdf\%2F591088453fbb6e13743faf58\&usg=AFQjCNGtVemlxKrTtVti1semyRulcbjKA. Acesso em: 28 maio 2019.

DWORKIN, Ronald. A virtude soberana: a teoria e prática da igualdade. Trad. Jussara Simões. 2. ed. São Paulo: WMF Martins Fontes.

GARGARELLA, Roberto. La sala de maquinas de la Constitución: dos siglos de Constitucionalismo en América Latina (1810-2010). Buenos Aires: Katz Editores, 2014.

HABERMAS, Jurgen. Mudança estrutural na esfera pública. Tradução de Flavio Kothe. Rio de Janeiro: Tempo Brasileiro, 1961.

HABERMAS, Jurgen. A inclusão do outro: estudos de teoria política. Tradução de George Sperber, Paulo Soethe, Milton C. Mota. 2.ed. São Paulo: Loyola, 2004.

HABERMAS, Jurgen. A Ética da Discussão e A Questão da Verdade. 3.ed. São Paulo: WMF Martins Fontes, 2013.

KANT, Immanuel. Fundamentação da metafísica dos costumes e outros escritos. São Paulo: Martin Claret, 2005. 
KEANE, John. A sociedade civil: velhas imagens, novas visões. Tradução de Maria José Figueiredo. Braga: Temas e debates, 2001.

KENNEDY, Ellen. Constitutional Failure: Carl Schmitt in Weimar. NC: Duke University Press, 2004.

KOZICKI, Katya. Democracia radical e cidadania: reflexões sobre a igualdade e a diferença no pensamento de Chantal Mouffe. In: FONSECA, Ricardo Marcelo (Org.). Repensando a Teoria do Estado. Belo Horizonte: Fórum, 2004.

KOZICKI, Katya. A democracia e a política como devir ético: entre Lévinas e Derrida. In: Manfredo Oliveira; Odilio Alves Aguiar; Luiz Felipe Netto de A. e Silva Sahd. (Org.). Filosofia Política Contemporânea. Rio de Janeiro: Vozes, 2003.

KOZICKI, Katya; GIAMBERARDINO, Pedro Ribeiro; LORENZETTO, Bruno Meneses. Política e direito: uma reflexão sobre a teoria da violência e da justiça. Anais do CONPEDI Salvador 2008. Disponível em:

http://www.publicadireito.com.br/conpedi/manaus/arquivos/anais/salvador/katya_kozicki.pdf. Acesso em: 28 maio 2019.

MAFFESOLI, Michel, A parte do diabo: resumo da subversão pós-moderna. Tradução de Clóvis Marques. Rio de Janeiro: Record, 2004.

MILOVIC, Miroslav. Considerações sobre Hannah Arendt e Chantal Mouffe. Disponível em: https://revistacult.uol.com.br/home/a-condicao-humana-na-modernidade/. Acesso em: 28 maio 2019.

MILOVIC, Miroslav. Arendt. 0 otimismo pensando a dignidade da política. Disponível em: http: //www.ihuonline.unisinos.br/index.php?option=com_content\&view=article\&td=621\&secao= 206. Acesso em: 28 maio 2019.

MOUFFE, Chantal. 0 regresso do político. Tradução de Joaquim Coelho Rosa. Lisboa: Gradiva. MOUFFE, Chantal. Sobre o político. Tradução Fernando Santos, São Paulo: WMF Martins Fontes, 2015.

OLSEN, Johan P. Desenho institucional em contextos democráticos. In: CUNHA, Eleonora Schettini M; THEODORO, Hildelano Delanusse. (Orgs). Desenho institucional, democracia e participação: conexões teóricas e possibilidades analíticas. [Local]: D `Placido Editora, 2014.

PATEMAN, Carole. Participação e teoria democrática. São Paulo: Paz e Terra, 1992.

PERUZZOTTI, Enrique E SMULVITZ, Catalina. Social accountability: an introduction. In: Enforcing the rule of law: social accountability in the new latin american democracies. [Local]: University of Pittsburgh Press, 2006.

RAWLS, John. Uma teoria de justiça. Tradução de Almiro Pisetta e Lenita Maria Rímoli Esteves. São Paulo: Martins Fontes, 2002. 
SAN MIGUEL, Mercedes López. "A política tem a ver com conflito" Entrevista de Chantal Mouffe. Disponível em: https://www.cartamaior.com.br/?/Editoria/Pelo-Mundo/ChantalMouffe-A-politica-tem-a-ver-com-o-conflito-/6/16166. Acesso em: 28 maio 2019.

SCHMITT, Carl. Teologia Politica I e II - Nova edição atualizada. Buenos Aires: Struhart, 2005

TULLY, James. Public Philosophy in a New Key. Volume I: Democracy and Civic Freedom. [Local]: Cambridge University Press, 2009. Disponível em:

http://www.cambridge.org/br/academic/subjects/politics-international-relations/politicaltheory/public-philosophy-new-key-volume-2?format=PB\&isbn=9780521728805. Acesso em: 28 maio 2019.

WOLIN, Sheldon. Qué significa la acción revolucionaria hoy. In: MOUFFE, Chantal (et al). Dimensiones de democracia radical: pluralismo, cidadania, comunidade. Buenos Aires: Prometeo Libros, 2012.

Recebido em: 30.08.2018 / Revisões requeridas em: 10.05.2019 / Aprovado em: 21.06.2019 / Publicado em: 14.09.2019

\section{COMO FAZER REFERÊNCIA AO ARTIGO (ABNT):}

KOZICKI, Katya; FALLER, Maria Helena Fonseca. Radicalizando a democracia, redefinindo a esfera pública, redesenhando instituições: um ensaio para maior participação popular na política. Revista Eletrônica do Curso de Direito da UFSM, Santa Maria, RS, v. 14, n. 3, e34534, set./dez. 2019. ISSN 1981-3694. DOI: http://dx.doi.org/10.5902/1981369434534. Disponível em: https://periodicos.ufsm.br/revistadireito/article/view/34534 Acesso em: dia mês. ano.

Direitos autorais 2019 Revista Eletrônica do Curso de Direito da UFSM

Editores responsáveis: Rafael Santos de Oliveira e Angela Araujo da Silveira Espindola

Esta obra está licenciada com uma Licença Creative Commons Atribuição-NãoComercial-SemDerivações 4.0 Internacional.

\section{SOBRE AS AUTORAS}

\section{KATYA KOZICKI}

Possui graduação em Direito pela Universidade Federal do Paraná (1986) e graduação em Ciências Econômicas pela Faculdade Católica de Administração e Economia (1988). Mestrado em Filosofia e Teoria do Direito pela Universidade Federal de Santa Catarina (1993) e doutorado em Direito, Política e Sociedade pela Universidade Federal de Santa Catarina (2000). Visiting Researcher Associate no Centre for the Study of Democracy, University of Westminster, Londres, 1998-1999. Atualmente é professora titular da Pontifícia Universidade Católica do Paraná e professora associada da Universidade Federal do Paraná, programas de graduação e pós-graduação em Direito. Tem experiência na área de Direito, com ênfase em Direitos Humanos, atuando principalmente nos seguintes temas: constitucionalismo e democracia, direitos humanos e democracia, justiça de transição, filosofia do direito, filosofia política e hermenêutica jurídica. Integrou o Comitê de Avaliação da área de Direito da CAPES (triênio 2008-10). Visiting Research Scholar, Benjamin N. Cardozo School of Law, Nova York, 2012-2013. Representante da área de Direito da Fundação Araucária 2013-2016. É pesquisadora (bolsista de produtividade em pesquisa) do CNPq, nível 2. Presidente da Comissão de Direitos Humanos da Universidade Federal do Paraná.

\section{MARia Helena fonseca Faller}

Doutoranda do Programa de Pós-Graduação em Direito Socioambiental e Sustentabilidade da Pontifícia Universidade Católica do Paraná. Mestre em Direito pela Universidade Federal de Santa Catarina. Professora de Teoria do Direito e Teoria da Constituição licenciada do Centro Universitário do Brasil ? UNIBRASIL. Presidente da Associação Nacional por uma Economia de Comunhão, organização que atua com foco no desenvolvimento do empreendedorismo ético, sustentável e inclusivo e em projetos de redução da pobreza. 